\title{
Review \\ Characteristics of Some Selected Methods of Rare Earth Elements Recovery from Coal Fly Ashes
}

\author{
Aleksandra Rybak ${ }^{1, *(1)}$ and Aurelia Rybak ${ }^{2}$ \\ 1 Department of Physical Chemistry and Technology of Polymers, Faculty of Chemistry, \\ Silesian University of Technology, 44-100 Gliwice, Poland \\ 2 Department of Electrical Engineering and Industrial Automation, Faculty of Mining, \\ Safety Engineering and Industrial Automation, Silesian University of Technology, 44-100 Gliwice, Poland; \\ aurelia.rybak@polsl.pl \\ * Correspondence: aleksandra.rybak@polsl.pl
}

check for updates

Citation: Rybak, A.; Rybak, A.

Characteristics of Some Selected Methods of Rare Earth Elements Recovery from Coal Fly Ashes . Metals 2021, 11, 142. https:// doi.org/10.3390/met11010142

Received: 31 October 2020 Accepted: 8 January 2021 Published: 12 January 2021

Publisher's Note: MDPI stays neutral with regard to jurisdictional clai$\mathrm{ms}$ in published maps and institutional affiliations.

Copyright: $\odot 2021$ by the authors. Licensee MDPI, Basel, Switzerland. This article is an open access article distributed under the terms and conditions of the Creative Commons Attribution (CC BY) license (https:// creativecommons.org/licenses/by/ $4.0 /)$.

\begin{abstract}
The article covers the issues related to the characteristics, application, and some methods of rare earth elements (REEs) recovery from coal fly ashes. REEs are elements with growing demand and a very wide range of application, especially when it comes to modern technologies. The conducted analysis and price forecast proved the existing upward tendency, and this confirmed the need to search for new REE sources, among industrial waste (proecological effect). The development of the REE recovery technology would involve solving several problems related to REE speciation, optimization of factors controlling their extractivity and selection of the REE separation method from obtained extraction solutions with a very extreme $\mathrm{pH}$ and complicated composition. The paper presented advantages and disadvantages of usually used methods of REE separation from coal fly ashes, like physical and acid-base leaching. It was also presented alternative REE recovery techniques in the form of membrane and biological methods and based on ion liquids (ILs) or chelating agents. The directions of further modifications, which will allow the efficient REE recovery were presented. The aim of this article was to propose specific solutions based on the creation of appropriate multistage method of REE recovery. It will be a combination of magnetic and size separation, acid-base leaching (including roasting in justified cases), removal of matrix elements with ILs (Al, Si, and Fe), and finally REE membrane separation, allowing one to obtain the appropriate process efficiency.
\end{abstract}

Keywords: REE recovery; coal fly ashes; separation; beneficiation; leaching

\section{Introduction}

The rare earth elements (REEs) group consists of seventeen chemical elements, including fifteen lanthanides and yttrium and scandium (occur in the same ore deposits and have similar chemical properties) [1,2]. All these elements exist in the form of trace quantities in natural materials, which are unevenly distributed around the world (estimated average concentration in the Earth's crust ranging from around 130 to $240 \mu \mathrm{g} / \mathrm{g}$ ) [1,3]. They could be categorized in many ways, among others as critical (Nd, Y, Eu, Dy, Tb, and Er), uncritical (Pr, Sm, La, and $\mathrm{Gd}$ ), and excessive (Tm, Ce, Ho, $\mathrm{Lu}$, and $\mathrm{Yb}$ ) or as light rare earth elements (LREEs) and heavy rare earth elements (HREEs) [1,4,5]. LREEs are in the form of bastnasite $\left((\mathrm{Ce}, \mathrm{La}) \mathrm{CO}_{3}(\mathrm{~F}, \mathrm{OH})\right)$ and monazite $\left((\mathrm{Ce}, \mathrm{La}, \mathrm{Nd}, \mathrm{Th}) \mathrm{PO}_{4}\right)$, while HREEs are usually present in the form of apatite, cheralite, eudialyte, loparite, phosphorites, rare-earth-bearing (ion adsorption) clays, secondary monazite, and xenotime [6-9]. The chemical and physical properties of rare earth elements are due to the peculiar nature of their electron configuration. These elements differ from one another by the number of inner-core electrons in the $4 \mathrm{f}$ subshell, from lanthanum to lutetium. Lanthanides have a similar electronic structure of the type $1 s^{2} 2 s^{2} 2 p^{6} 3 s^{2} 3 p^{6} 3 d^{10} 4 s^{2} 4 p^{6} 4 d^{10} 4 f^{n} 5 d^{1} 6 s^{2}$ or $4 f^{n+1} 6 s^{2}$. The $4 f$ electrons have lower energies and are a part of the ion core, lying inside, surrounded by outer 
valence electrons. Therefore, they do not participate directly in the formation of bonds with other elements and the formation of chemical compounds. Hence their chemical similarity, mutual presence in various minerals, and difficulties with their separation. The outer or valence electrons of the 14 lanthanides and lanthanum are the same, $5 \mathrm{~d}^{1} 6 \mathrm{~s}^{2}$ or $6 \mathrm{~s}^{2}$, for the scandium $3 \mathrm{~d}^{1} 4 \mathrm{~s}^{2}$, and for yttrium $4 \mathrm{~d}^{1} 5 \mathrm{~s}^{2}$. However, there are some differences in the chemical properties of the lanthanides due to the lanthanide contraction or the mixing of the $4 \mathrm{f}$ electrons with valence electrons. The phenomenon called lanthanide contraction is caused by an increase in nuclear charge that is not completely screened by the additional $4 \mathrm{f}$ electron as it moves from one lanthanide to the next. Therefore, electrostatic attraction of electrons by the nucleus increases, and, thus, the atomic and ionic radii decrease. This is an important characteristic property of lanthanides that results in two features. Firstly, there are only small differences in their chemical properties as their atomic number increases, because of the similar ionic radii and valence states. Secondly, there are major differences in REE atomic spectra and magnetic properties. This contraction is also responsible for the decreased basicity from lanthanum to lutetium and is the basis of various separation techniques $[1,10]$.

Namely, the normal valence state is mainly the trivalent oxidation state, $\mathrm{Ln}(\mathrm{III})$. However, cerium could occur in the tetravalent oxidation state, $\mathrm{Ce}(\mathrm{IV})$, and europium and ytterbium occur in the divalent oxidation states, $\mathrm{Eu}(\mathrm{II})$ and $\mathrm{Yb}(\mathrm{II})$. Cerium, praseodymium, and terbium lose electron $4 \mathrm{f}$ when they become ionic, and their radii decrease. On the other hand, samarium, europium, and ytterbium gain the $4 \mathrm{f}$ electron during the transition to the ionic state and their radii increase. This can be used to separate $\mathrm{Ce}, \mathrm{Eu}$, and $\mathrm{Yb}$ from the rest of the trivalent ions. The electronic structure also influences their melting points, which increase with increasing atomic number (from $798^{\circ} \mathrm{C}$ for cerium to $1663{ }^{\circ} \mathrm{C}$ for lutetium), while the melting points of scandium and yttrium are comparable to the last representatives of the trivalent lanthanides. In turn, the low melting points of europium and ytterbium result from their divalence. The boiling points of rare earth elements also differ. This is due to the difference in electronic states when they are solid or gaseous. Namely, the boiling points of $\mathrm{Ce}, \mathrm{Pr}, \mathrm{Y}$, and $\mathrm{Lu}$ are the highest, while those of $\mathrm{Eu}$ and $\mathrm{Yb}$ are the lowest. This is because Ce, $\mathrm{Pr}, \mathrm{Y}$, and Lu have three outer electrons in both states, while $\mathrm{Eu}$ and $\mathrm{Yb}$ only have two outer electrons. The remaining lanthanides are trivalent solids, but their gaseous forms have two outer electrons. The electrical resistivity of rare earth elements varies from 29 to $134 \mu \Omega \cdot \mathrm{cm}$. Most trivalent REEs have resistance in the range $57-90 \mu \Omega \cdot \mathrm{cm}$. The lowest resistance $29 \mu \Omega \cdot \mathrm{cm}$ relates to the divalent $Y \mathrm{~b}$, while the highest to $\mathrm{Gd}$ and $\mathrm{Tb}$, which result from the magnetic contribution to the electrical resistivity near the magnetic ordering temperature of a material. In turn, the magnetic properties of rare earth elements depend on the number of unpaired $4 \mathrm{f}$ electrons. Metals that do not have unpaired electrons such as $\mathrm{Sc}, \mathrm{Y}, \mathrm{La}, \mathrm{Lu}$, and $\mathrm{Yb}$ are weakly magnetic. The remaining lanthanides from Ce to $\mathrm{Tm}$ are strongly magnetic because they have unpaired $4 \mathrm{f}$ electrons. Most of them have at least two magnetic structures. Where $\mathrm{Gd}$, in which all the $4 \mathrm{f}$ spins are aligned in one direction, is ferromagnetic. The remaining REEs, in turn, have $4 \mathrm{f}$ spins that align antiparallel to each other, which is why they are antiferromagnetic [10].

As for the chemical reactivity of rare earth elements, it depends largely on their type and the difference between light and heavy lanthanides. For example, light lanthanides oxidize much faster than heavy lanthanides (gadolinium to lutetium), scandium, and yttrium. This difference is partly due to the variability of the resulting oxide product. For example, light lanthanides (from lanthanum to neodymium) form the hexagonal A-type $\mathrm{REE}_{2} \mathrm{O}_{3}$ structure; middle lanthanides (from samarium to gadolinium) form a monoclinic B-type $\mathrm{REE}_{2} \mathrm{O}_{3}$ phase; while heavy lanthanides, scandium, and yttrium form a cubic C-type $\mathrm{REE}_{2} \mathrm{O}_{3}$ modification. Metallic europium, which has the body-centered cubic (bcc) crystal structure, oxidizes the most rapidly of all rare earth elements, and in humid air forms hydrate oxide $\mathrm{Eu}(\mathrm{OH})_{2} \cdot \mathrm{H}_{2} \mathrm{O}$, which is an unusual reaction product because all other rare earth metals form oxides. REEs react vigorously with all acids except hydrofluoric acid (HF), releasing $\mathrm{H}_{2}$ gas and forming the corresponding rare earth anionic compound. Rare 
earth metals also react readily with hydrogen gas to form $\mathrm{REEH}_{2}$ and, under high hydration conditions, an $\mathrm{REEH}_{3}$ phase-except Sc, which does not form a trihydrate. They are also the most electropositive elements, forming an ionic bond in solids, so they are extremely reactive with hydrogen and electronegative elements such as halogens, oxygen, nitrogen, and sulphur, creating, stable hydrides, halides, oxides, nitrides, and sulphides. This property is used extensively for the removal of impurities from high-purity atmospheres or for the preparation of hydrogen storage compounds used in rechargeable secondary batteries. Just like other reactive metals, REE physical properties are strongly influenced by the amount of interstitial impurities (oxygen, nitrogen, carbon, and hydrogen) present in their metal lattice structure $[4,10]$. Currently, REE become more and more important because of their unique chemical, physical, catalytic, luminescent, and magnetic features and of course many industrial applications (electronics, clean energy technologies, defense, optics, automotive, agriculture, medicine, energy, etc.) [11]. For instance, neodymium is applied in super magnets for disk drives, cerium in autocatalysts and all in flat-panel TVs production and smart batteries for electric vehicles [1]. Due to their application all modern gadgets can be more efficient, smaller, faster, and lighter. Therefore, the demand for REE will continue to increase in the near future [6].

In the twentieth century, REE were mined mainly in California and Australia [12]. Currently, the main REEs producers are China (63\%), Russia (14\%), Australia (10\%), USA, Myanmar, Brazil, and India (Figure 1) [1]. Except that also Kazakhstan, Kyrgyzstan, Tajikistan, Uzbekistan, and Turkmenistan show some REE mineral occurrence [13,14]. However, the largest REE exporter is China. Its monopoly forces other countries to look for other alternative sources and developing REE recovery techniques. Except that the conventional REE mining techniques, which include ore deposits, are energy-intensive and generate significant volumes of toxic wastes and acidic wastewater [3]. Therefore, new sources of REE should be sought. It turned out that coal fly ashes could be one of their sources.

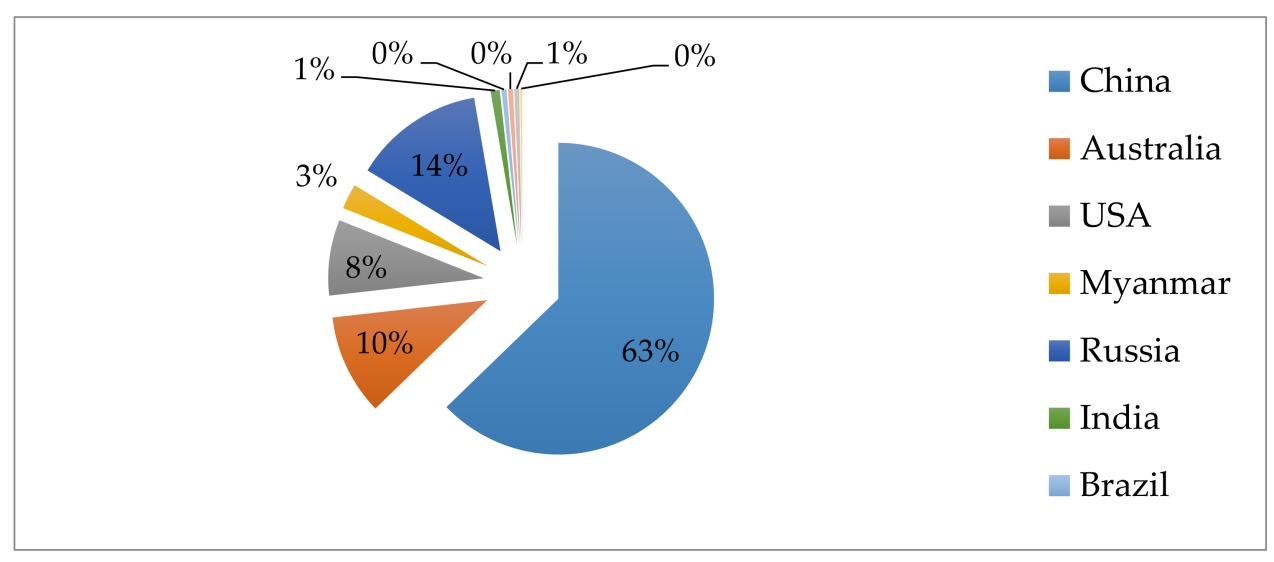

Figure 1. Rare earth element (REE) production in the world in 2020.

Coal fly ashes created during the coal combustion contain a higher fraction of critical REE ( $>30 \%$ of total REE) than REE-bearing ores. Except that, they are generated annually worldwide in the amount of over 750 million tonnes $[11,15,16]$. Additionally, if the appropriate cost-effective recovery method would be developed, then they could become a perfect future source of REEs.

Despite the fact that there are many publications regarding fly ash utilization, only few of them are taking them as a potential source of REE [17]. The most investigations were concentrated on their use in the cement industry $[18,19]$ or production of synthetic zeolites [20-22], and their usage as potential REE source is a quite new research area. Coal fly ashes were usually utilized in civil engineering [23], mine reclamation and agricultural application $[17,24]$, like for instance: raw material in Portland cement manufacture, replacement for cement in concrete and grout, cement replacement in precast concrete products, 
aggregate for the stabilization of highway subgrades, aggregate for road base material, material for structural fill, raw material for metal reclamation, filler material in plastics, sanitary landfill cover or liner, backfill for controlling subsidence in abandoned mines, backfill for fighting mine fires, amelioration of soils, raw material in brick manufacture, mine subsidence and acidic drainage control, material for absorbing oil spills and absorbent for dewatering sewage sludge, geopolymers, glass-ceramics, water and wastewater treatment, agriculture, production of synthetic zeolites, etc. [17]. Except that a storage of coal fly ashes also constitutes an environmental hazard. Heavy metals contained in the ashes can penetrate the soil and groundwater. In addition, there may be so-called secondary dusting. That is why the possibility of managing ashes excludes danger of environment contamination and the need to incur fees for placing waste in landfills [25].

The aim of this paper was to present the necessity to find new REE sources and the advantages and disadvantages of techniques used for REE recovery from coal fly ashes. The next goal was to propose, on the basis of the presented considerations, specific solutions based on the creation of the appropriate multistage method of REE recovery, which is a combination of magnetic and size separation, acid-base leaching (including roasting in justified cases), removal of matrix elements ( $\mathrm{Al}, \mathrm{Si}$, and $\mathrm{Fe}$ ) with ionic liquids (ILs), and finally REE membrane separation, which will allow one to obtain the appropriate process efficiency.

\section{Results}

\section{Economic Aspects of REE Production}

In connection with the development of technology and, consequently, the growing demand for REE from year to year, new sources should be sought. The lack of universal availability also shapes the prices of REE, which are often subject to very rapid increases.

Figure 2 shows the time series of the prices of four selected rare earth elements and their forecast until 2021. These are one of the most important and most widely used elements: neodymium $(\mathrm{Nd})$, praseodymium $(\mathrm{Pr})$, terbium $(\mathrm{Tb})$, and dysprosium $(\mathrm{Dy})$. Data on the prices of selected REEs was obtained from the website Kitco [26].

Autoregressive integrated moving average (ARIMA) class models $[27,28]$ were used to prepare the forecast. ARIMA models are based on autoregression and a moving average. They are used in stationary or reduced to stationary series. ARIMA can be based on a moving average, autoregression, or both. Their principle of operation is based on the use of autocorrelation, i.e., the correlation of time series elements with the same elements but delayed in time.
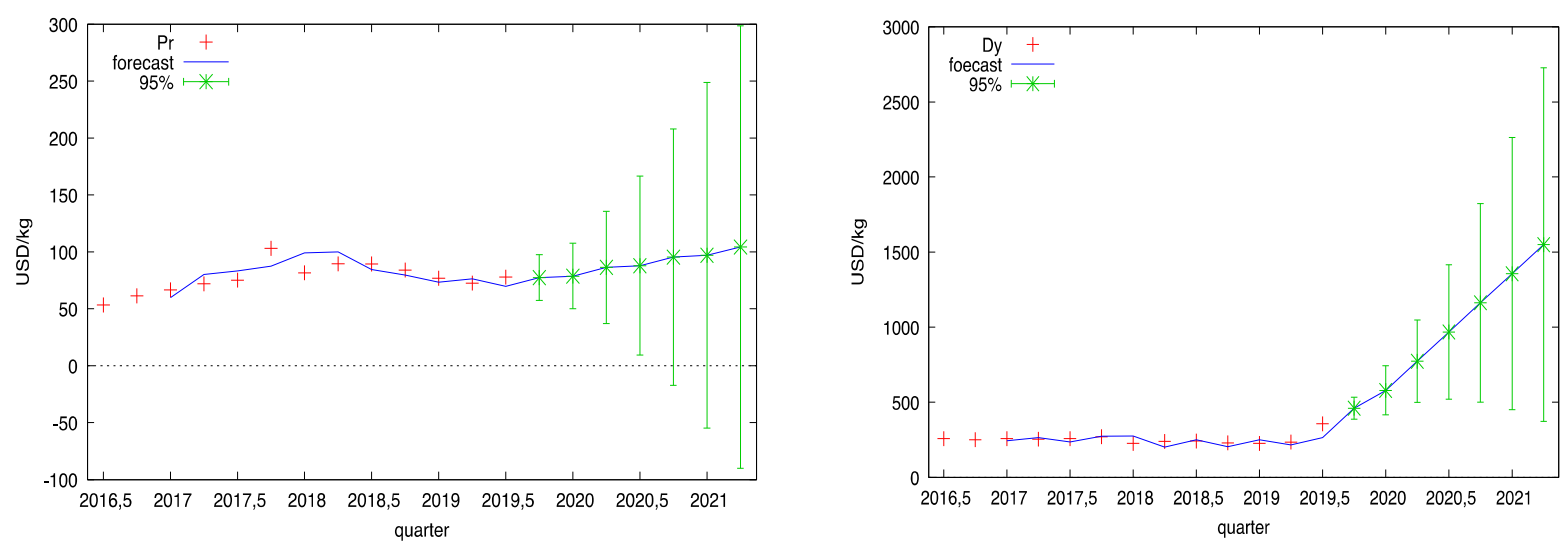

Figure 2. Cont. 

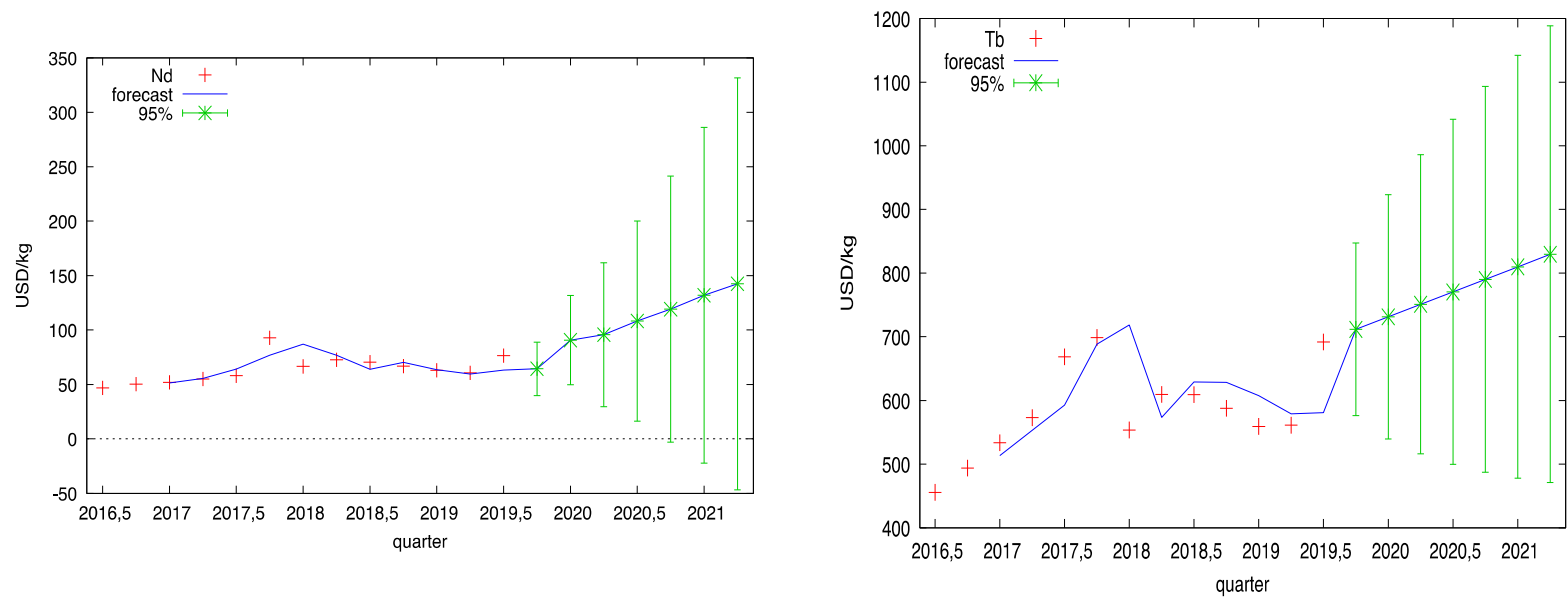

Figure 2. Prices of selected REEs with a forecast until mid-2021.

AR autoregression model:

$$
y_{t}=\varphi_{0}+\varphi_{1} y_{t-1}+\varphi_{2} y_{t-2}+\ldots+\varphi_{p} y_{t-p}+e_{t}
$$

where:

$y_{t}, y_{t-1}, y_{t-2}, \ldots, y_{t-p}-$ value of the forecast variable at time or period $t, t-1, t-2$, and $t-p$,

$\varphi_{0}, \varphi_{1}, \ldots, \varphi_{t-p}$-model parameters, and

$p$-delay.

Moving average model MA:

$$
y_{t}=\theta_{0}+e_{t}-\theta_{1} e_{t-1}-\theta_{2} e_{t-2}-\ldots-\theta_{q} e_{t-q}
$$

where:

$e_{t}, e_{t-1}, \ldots, e_{t-q}$-rest of the model in periods $t \ldots, t-q$, and

$q$-delay.

The AR, MA, and ARMA models can be universally described as ARIMA $(p, d, q)$ where $p$ is the number of autoregressions, $d$ is the number of differential transformations, and $q$ is the time delay. Model validation was carried out using ex post forecast errors (mean absolute percentage error (MAPE) and mean percentage error) [29,30], information criteria (Akaike (AIC), Hannan Qiunn (HQC), and Bayesian information criterion (BIC)), and normality tests of residue distribution (Jarque-Bera test) and residue autocorrelation (Durin-Watson). From among the several hundred models created, those were selected that were the most optimal combination of all factors considered during their validation. From the collected models, the selected ones were characterized by both the lowest values of the information criterion and ex post errors. Mainly the models were compared and verified using the MAPE error (Table 1), the value of which in any of the models presented in the article did not exceed $11 \%$. Therefore, it can be concluded that the models are characterized by high accuracy.

Table 1. MAPE error value of price forecast for selected rare earth elements.

\begin{tabular}{ccccc}
\hline Element & Tb & Pr & Nd & Dy \\
\hline MAPE error $(\%)$ & 8.55 & 10.1 & 9.12 & 10.6 \\
\hline
\end{tabular}

The charts in Figure 2 show the actual data (marked in red), the price forecasts of selected REEs until 2021 (marked in blue) and the confidence intervals of the forecasts (green series). 
The confidence interval of the forecast is the range in which the forecasted value will lie with a given probability. For example, if the Dy price in the second quarter of 2021 has a $95 \%$ confidence interval between $\$ 372$ and $\$ 2728$, there is a $95 \%$ probability that the price will be in the range \$372-\$2728. The confidence interval can be used for scenario planning, which is an appropriate method to predict the future in a turbulent environment. Both the original time series and the forecast based on them indicate a systematic increase in the prices of rare earth elements.

Table 2 presents a summary of changes in prices of selected elements in 2016-2019 and for forecasted price levels. This analysis indicates that investments related to the recovery of REE will certainly be profitable. In Poland, the source of REE may be fly ash generated as a byproduct of hard coal combustion [31]. Since the concentration of rare earth elements in ashes is several dozen times higher than in coal [18]. It has been estimated that from $1 \mathrm{Mg}$ (1 tonne) of ash, rare earth elements worth up to 600 USD can be produced (the cost of $1 \mathrm{Mg}$ of ashes is about $13 \mathrm{USD}$ ) [32]. Even considering the recovery of REE from ashes generated in Poland (up to 300 ppm LREE and up to 150 ppm HREE) in the amount of up to 12 million tons per year (in EU15 about 30 million tons, EU28 over 88 million tons, and in EU, estimated based on coal consumption over 124 million tons). The process will continue to be profitable, yielding large profits of up to several hundred million dollars a year.

Table 2. Price changes for selected REEs in 2016-2019 and 2019-2021.

\begin{tabular}{ccccc}
\hline Year & Nd & Pr & Tb & Dy \\
\hline $2019 / 2016$ & $63 \%$ & $46 \%$ & $52 \%$ & $39 \%$ \\
$2021 / 2019$ & $86 \%$ & $34 \%$ & $20 \%$ & $334 \%$ \\
\hline
\end{tabular}

The data presented in Figure 2, regarding empirical values, forecasts, and confidence interval for the created ARIMA models are also included in Table 3.

Table 3. Empirical values, forecasts, and confidence interval for the created ARIMA models.

\begin{tabular}{|c|c|c|c|c|c|c|c|c|}
\hline \multicolumn{5}{|c|}{$\mathbf{T b}$} & \multicolumn{4}{|c|}{ Pr } \\
\hline Year & $\begin{array}{c}\text { Empirical } \\
\text { Data }\end{array}$ & Forecast & $\begin{array}{c}\text { Confidence } \\
\text { Interval-Lower } \\
\text { Bound }\end{array}$ & $\begin{array}{c}\text { Confidence } \\
\text { Interval-Upper } \\
\text { Bound }\end{array}$ & $\underset{\text { Data }}{\text { Empirical }}$ & Forecast & $\begin{array}{c}\text { Confidence } \\
\text { Interval-Lower } \\
\text { Bound }\end{array}$ & $\begin{array}{c}\text { Confidence } \\
\text { Interval-Upper } \\
\text { Bound }\end{array}$ \\
\hline 2017:1 & 533 & 514 & & \multirow{11}{*}{. } & 66 & 60 & & \multirow{11}{*}{ - } \\
\hline 2017:2 & 573 & 553 & & & 72 & 80 & & \\
\hline 2017:3 & 668 & 593 & & & 75 & 83 & & \\
\hline 2017:4 & 699 & 688 & & & 103 & 88 & & \\
\hline 2018:1 & 553 & 719 & & & 81 & 99 & & \\
\hline 2018:2 & 609 & 573 & & & 89 & 100 & & \\
\hline 2018:3 & 608 & 629 & & & 89 & 85 & & \\
\hline 2018:4 & 587 & 629 & & & 84 & 80 & & \\
\hline 2019:1 & 559 & 608 & & & 76 & 73 & & \\
\hline 2019:2 & 561 & 579 & & & 72 & 76 & & \\
\hline 2019:3 & 692 & 581 & & & 78 & 70 & & \\
\hline 2019:4 & \multirow{7}{*}{-} & 712 & 576 & 847 & \multirow{7}{*}{-} & 78 & 5 & 248 \\
\hline 2020:1 & & 731 & 540 & 923 & & 79 & 4 & 298 \\
\hline 2020:2 & & 751 & 516 & 986 & & 86 & 57 & 98 \\
\hline $2020: 3$ & & 771 & 500 & 1042 & & 88 & 50 & 108 \\
\hline 2020:4 & & 790 & 487 & 1094 & & 95 & 37 & 136 \\
\hline 2021:1 & & 810 & 478 & 1142 & & 97 & 9 & 167 \\
\hline 2021:2 & & 830 & 471 & 1189 & & 104 & 17 & 208 \\
\hline
\end{tabular}


Table 3. Cont.

\begin{tabular}{|c|c|c|c|c|c|c|c|c|}
\hline \multicolumn{5}{|c|}{$\mathrm{Nd}$} & \multicolumn{4}{|c|}{ Dy } \\
\hline Year & $\begin{array}{c}\text { Empirical } \\
\text { Data }\end{array}$ & Forecast & $\begin{array}{l}\text { Confidence } \\
\text { Interval-Lower } \\
\text { Bound }\end{array}$ & $\begin{array}{l}\text { Confidence } \\
\text { Interval-Upper } \\
\text { Bound }\end{array}$ & $\underset{\text { Data }}{\text { Empirical }}$ & Forecast & $\begin{array}{c}\text { Confidence } \\
\text { Interval-Lower } \\
\text { Bound }\end{array}$ & $\begin{array}{c}\text { Confidence } \\
\text { Interval-Upper } \\
\text { Bound }\end{array}$ \\
\hline 2017:1 & 52 & 51 & & \multirow{11}{*}{. } & 258 & 243 & & \multirow{11}{*}{. } \\
\hline 2017:2 & 55 & 56 & & & 255 & 265 & & \\
\hline 2017:3 & 58 & 64 & & & 258 & 236 & & \\
\hline 2017:4 & 92 & 77 & & & 271 & 274 & & \\
\hline 2018:1 & 66 & 87 & & & 226 & 276 & & \\
\hline 2018:2 & 72 & 77 & & & 239 & 201 & & \\
\hline 2018:3 & 70 & 64 & & & 241 & 251 & & \\
\hline 2018:4 & 66 & 70 & & & 230 & 204 & & \\
\hline 2019:1 & 62 & 64 & & & 226 & 250 & & \\
\hline 2019:2 & 61 & 60 & & & 235 & 216 & & \\
\hline 2019:3 & 76 & 63 & & & 357 & 265 & & \\
\hline 2019:4 & \multirow{7}{*}{-} & 64 & 40 & 89 & \multirow{7}{*}{-} & 461 & 387 & 534 \\
\hline 2020:1 & & 91 & 50 & 132 & & 579 & 415 & 743 \\
\hline 2020:2 & & 96 & 30 & 162 & & 774 & 499 & 1048 \\
\hline $2020: 3$ & & 108 & 16 & 200 & & 968 & 521 & 1415 \\
\hline $2020: 4$ & & 119 & 13 & 242 & & 1162 & 501 & 1823 \\
\hline 2021:1 & & 132 & 10 & 286 & & 1356 & 450 & 2262 \\
\hline 2021:2 & & 142 & 5 & 332 & & 1550 & 373 & 2728 \\
\hline
\end{tabular}

\section{Characterization and Recovery Methods of REE from Coal Fly Ashes}

\subsection{Methods Used for the Physicochemical Characterization of Coal Fly Ashes}

The origin from various coal regions and different geochemical composition of feed coal stock can influence the final composition of coal fly ash. During the combustion process, metals included in the coal pyrite structure are concentrated in the fly ash. They can be adsorbed on the surface of glassy spherical fly ash particles and then can be quite mobile and washable under low $\mathrm{pH}$ conditions. Their distribution and leaching from ash particles depend on many parameters, mainly on the amount of unburned carbon and iron in the fly ash, the type of leaching reagents, solid to liquid ratio, $\mathrm{pH}$, temperature, duration, etc. [17]. So, the methods of efficient REEs extraction would depend on these parameters and ash characteristics [11,19].

First studies of REE recovery from coal fly ashes focused on the glass phase and application of strong acids and alkalis in high temperatures. Additionally, physical separation methods (particle size and magnetic and density separations) were used to enrich samples in REE. However, in a meantime, it was found that everything depended on a characteristic of examined fly ashes (consisting mainly of glass phase or oxides and apatite), which have various REE extractabilities.

To characterize the coal fly ash properly and then to select the most optimal method of REE recovery, the REE extractability and their speciation should be examined [5].

Some studies suggested that the REE predominant phase is the amorphous aluminosilicate glass, while another suggested their presence in carbonate, phosphate, and silicate minerals (for instance zircon) $[1,5,33]$. So, this situation requires some new analytical techniques both of micro- and bulk-scale to study the correlation between REE extractability and speciation in coal fly ashes [5]. To examine the REE's extractability, two methods were used, like sequential chemical extraction and acid leaching. However, they have some limitations, like problems with interpretation of the related mineral phases, because it could come to incomplete or concomitant dissolution of phases or change of the original phases. For instance, Vassilev et al. proposed conventional separation procedure and recovered six various fractions. So, the first fraction $(0.2-1.1 \%)$ was obtained by sink-float separation of fly ashes in distilled water. The second fraction $(0.2-0.6 \%)$ was separated by evaporation 
and crystallization of the water-soluble alkaline solutions leached from ashes. The third one $(0.7-4.1 \%)$ was isolated during dry magnetic separation of the residue from step 2 . The fourth $(1.6-22.8 \%)$ was obtained by sieving $(>100 \mathrm{~mm})$ of the residues from step 3 . The next fraction $(0.02-0.28 \%)$ was recovered by sink-float separation in bromoform of the residues from the previous stage. The last, sixth fraction was improved fly ash residue (71.5-97.1\%). They have also stated that coal fly ashes consist mainly of aluminosilicate glass, mullite, quartz, char, kaolinite-metakaolinite, hematite, cristobalite, plagioclase, K-feldspar, melilite, anhydrite, wollastonite, magnetite, and corundum [34].

In turn to analyze REE speciation many techniques were used, among others: laser ablation inductively coupled plasma mass spectrometry (ICP-MS) [35-37], scanning/ transmission electron microscopy coupled with energy dispersive $\mathrm{X}$-ray spectroscopy (S/TEM-EDX) [5], synchrotron X-ray microscopy and spectroscopy, electron probe microanalysis (EPMA) [5], XRD, micro-X-ray fluorescence ( $\mu \mathrm{XRF)}$ imaging, micro-X-ray absorption near edge structure spectroscopy ( $\mu$ XANES) [5,38,39], etc.

Since all these techniques have some limitations, to obtain the whole picture of REE speciation in complex matrices of fly ashes, the comparison and cross-validation of obtained results from various techniques is required. For instance, Liu et al. using the sequential extraction defined four different fractions, like: acid-soluble (carbonates), reducible ( $\mathrm{Fe}-\mathrm{Mn}$ oxides), oxidizable (organic matter and sulphide), and residue (silicates). In turn, using the acid leaching, the REE extractability was examined as a function of $\mathrm{pH}$. Using this method Liu et al. identified REE-bearing phases: in the form of discrete particles or associated with the glass phase (capture of REE during glass cooling and agglomeration). However, they also found that the REE fractions (oxides, apatite, Fe oxides, and phosphates) identified by two different methods, like XANES and acid leaching, did not completely correlate with each other. It was found that combining the results from different methods, such as SEM-EDX, $\mu$ XRF/ $\mu$ XANES, mass XANES, and acid leaching allows an in-depth analysis of the interrelationships between speciation, distribution, and extractivity of REE [5].

Another technique used to study the REE distribution was the sensitive high massresolution (SHRIMP-RG) ion microprobe. This method allowed one to determine grainscale REE partitioning in coal fly ash samples. The obtained results confirmed the presence of REE in aluminosilicate phase, which was consistent with previous results (a strong positive correlation between $\mathrm{Al}$ and REE content). It was found that the aluminosilicates without other main elements usually have REE content similar or slightly lower than the REE content in the bulk sample. While aluminosilicate glasses enriched in $\mathrm{Ca}$ and Fe are characterized by similar or higher REE content than in the bulk sample. In turn, the coexisting quartz and high silica glass in fly ash has significantly lower REE content. While REEs content in the Fe-oxides phase is more variable. The results suggested that the extraction of REE from the aluminosilicate glass fraction would allow the recovery of a significant amount of REEs. That is why many researchers have focused on this fraction to recover REEs from coal fly ashes [40].

\subsection{Physical Separation Methods for REE Recovery}

In traditional processes for REE obtaining from REE ores are used physical separation methods, like magnetic, size and density separation, electrostatic separation, and flotation. However, their application in REEs recovery from fly ashes was rather limited. The flotation process is effective for the particle size range from 10 to $100 \mu \mathrm{m}$. So, the process of fly ashes flotation for REE minerals below $5 \mu \mathrm{m}$ had lower efficiency (20-30\% of REE recovery). The conventional flotation with the usage of fatty acids and octanohydroxamic acid (OHA) was not efficient [41-43]. That is why the novel ultrafine particle concentrator known as a hydrophobichydrophilic separator (HHS) was introduced. Further modification of rare earth mineral concentration process consisted in the application of the primary and secondary hydrophobizing agent (potassium octylhydroxamate (KOHX) and sorbitan monooleate (SMO), respectively). Honaker et al. achieved in that way, the enrichment ratio 53:1 [38]. 
In turn, Dai et al. used the magnetic separation method. Using this method, they have separated fly ash in three fractions: magnetic, MCQ (mullite + corundum + quartz), and glass phases. They have also stated that depending on the type of REEs they were enriched in various phases. Namely heavy REE were more enriched in the glass phase, when light REE were more enriched in the magnetic and MCQ phases [41,44-46].

The content of REE in fly ash depended also on its granulation and it was found that their concentration increased with the decrease of particle size $[17,39,47]$. Considering, the influence of these parameters on REE concentration, Blissett et al. used a multistage REE enrichment consisting of froth flotation, magnetic separation, and hydrocyclone separation, getting enrichment of REE from 419 to $529 \mathrm{ppm}$ [43]. If it is going about density separation it was found that REE concentration was not the highest in the highest density fractions as it was expected. That indicates again that REE are trapped in other minerals and are not effectively released using physical methods $[38,39,41]$.

\subsection{Acid and Alkaline Leaching Methods}

According to many authors the REEs in coal fly ashes are mainly in the form of fine minerals dispersed in the aluminosilicate glass phase (strong correlation between $\mathrm{Al}$ oxide and REE content). Analysis of mineralogical composition of coal fly ashes has shown that they consist of over $70 \%$ of amorphous glass and almost $30 \%$ of mineral phases, like quartz, iron oxides, and mullite $[33,48]$. While their dissolution in $4 \% \mathrm{HF}$ has shown that about $90 \%$ of REEs is associated with amorphous glass. This means that aggressive extraction methods will be required [11]. As the main target will be the aluminosilicate phase, the methods used for Al recovery (acid leaching, sintering with alkali reagents followed by acid leaching, and pyrometallurgical methods) may be applicable to REE extraction [49-52]. The recovering process of REEs from coal fly ashes consists of a few steps, firstly the REE should be leached into solution and secondly extracted from the solution with appropriate reagents. This first step is very often the limiting one, because of low leaching efficiency. Usually as a first step of REE extracting from fly ash acid leaching was used. The next method was alkaline leaching and the method combined acid and alkaline leaching, which was introduced to reduce the reagents usage and maximize the REE extraction efficiency. So far, an extensive research was done on characterization of fly ash composition, but very little research has been done on effective REE extraction methods from coal fly ash (no commercialized technologies until now) [19]. Basic data on exemplary acid and alkaline leaching methods used for REE recovery are presented in Table 4.

Table 4. Summary of data on selected acid and alkaline leaching methods for REE recovery.

\begin{tabular}{|c|c|c|c|c|c|}
\hline REE Source & Method & Leaching Conditions & REE Recovery & Ash Composition & Ref. \\
\hline Ash-EOP & Acid leaching & $\begin{array}{c}\mathrm{H}_{2} \mathrm{SO}_{4}, \text { agitation, } 30{ }^{\circ} \mathrm{C}, 60 \\
{ }^{\circ} \mathrm{C}, 80^{\circ} \mathrm{C}, 2 \mathrm{~h}\end{array}$ & $\begin{array}{c}\text { Sc 79\%; Y 114\%; La 90\%; Ce } \\
\text { 96\%; Pr 98\%; Nd 75\%; Sm } \\
\text { 79\%; Eu 102\%; Gd 106\%; Dy } \\
\text { 83\%; Tb 103\%; Lu 76\%; Yb } \\
62 \%\end{array}$ & $\begin{array}{c}49.1 \% \mathrm{SiO}_{2}, 29.8 \% \\
\mathrm{Al}_{2} \mathrm{O}_{3}, 7.3 \% \mathrm{Fe}_{2} \mathrm{O}_{3} \\
2.35 \% \mathrm{CaO}, 0.97 \% \mathrm{MgO}\end{array}$ & [53] \\
\hline $\begin{array}{l}\text { Coal ash from } \\
\text { electrical power } \\
\text { company in Japan }\end{array}$ & Acid leaching & $\begin{array}{c}\mathrm{H}_{2} \mathrm{SO}_{4}, 30-80{ }^{\circ} \mathrm{C}, 2 \mathrm{~h} \\
6 \mathrm{M} \mathrm{HNO}_{3}, 30 \mathrm{~g} \text { ash } / \mathrm{L}, 85 \\
{ }^{\circ} \mathrm{C}, 100 \mathrm{rpm}, 1 \mathrm{~h}\end{array}$ & $\begin{array}{l}8-45 \% \text { REE } \\
90.5 \% \text { REE }\end{array}$ & $\mathrm{N} / \mathrm{A}$ & [54] \\
\hline $\begin{array}{l}\text { CFA from the Panbei } \\
\text { Power } \\
\text { Plant in China }\end{array}$ & Acid leaching & $\begin{array}{c}3 \mathrm{M} \mathrm{HCl}, 200 \mathrm{rpm}, 60^{\circ} \mathrm{C}, \\
10: 1,2 \mathrm{~h}\end{array}$ & $\begin{array}{c}71.9 \% \mathrm{La}, \mathrm{Ce} 66.0 \% \text {, and } \mathrm{Nd} \\
61.9 \%\end{array}$ & $\begin{array}{c}\mathrm{SiO}_{2} 47 \% \%, \mathrm{Al}_{2} \mathrm{O}_{3} \\
22.5 \%, \mathrm{Fe}_{2} \mathrm{O}_{3} 6.84 \% \\
\mathrm{CaO} 4.52 \%, \mathrm{MgO} 1.26 \%\end{array}$ & {$[55]$} \\
\hline $\begin{array}{l}\text { EDF } \\
\text { Rybnik Inc. } \\
\text { Power Plant }\end{array}$ & $\begin{array}{l}\text { Alkaline or acid } \\
\text { leaching }\end{array}$ & $\begin{array}{c}9 \mathrm{M} \mathrm{H}_{2} \mathrm{SO}_{4} \text { or } 6 \mathrm{M} \mathrm{NaOH}, \\
10: 1, \mathrm{pH}: 1,4,7,10,13 \\
\text { room temp., } 5 \text { days }\end{array}$ & $\begin{array}{c}\text { average maximum recovery } \\
\text { Nd: } 64.5 \%, \text { Eu } 96.9 \%, \mathrm{~Tb} \\
91.1 \%, \mathrm{Y} 89.1 \% \text { at } \mathrm{pH} 1 \\
\text { below the limit of } \\
\text { detection-basic conditions }\end{array}$ & - & [56] \\
\hline
\end{tabular}


Table 4. Cont.

\begin{tabular}{|c|c|c|c|c|c|}
\hline REE Source & Method & Leaching Conditions & REE Recovery & Ash Composition & Ref. \\
\hline $\begin{array}{l}\text { Coal fly ash from coal } \\
\text { power plant in Ohio, } \\
\text { USA }\end{array}$ & $\begin{array}{c}\text { Magnetic } \\
\text { separation particle } \\
\text { size separation } \\
\text { alkaline treatment }\end{array}$ & $\begin{array}{l}5 \mathrm{M} \mathrm{NaOH}, \\
\text { ratio } 1: 20,100^{\circ} \mathrm{C}, 2 \mathrm{~h} \\
\text { 10-cycle } \mathrm{NaOH} \\
\text { hydrothermal } \\
\text { treatment }\end{array}$ & REE $170 \%$ & $\begin{array}{c}\text { more than } 85 \% \text { of } \mathrm{SiO}_{2} \\
\mathrm{Al}_{2} \mathrm{O}_{3} \text { and } \mathrm{Fe}_{2} \mathrm{O}_{3}\end{array}$ & [57] \\
\hline $\begin{array}{l}\text { Fire Clay seam coal } \\
\text { middlings }\end{array}$ & $\begin{array}{l}\text { Flotation, magnetic } \\
\text { separation with } \\
\text { acid leaching }\end{array}$ & $1 \mathrm{M} \mathrm{HNO}_{3}, 75^{\circ} \mathrm{C}, 5 \mathrm{~h}$ & 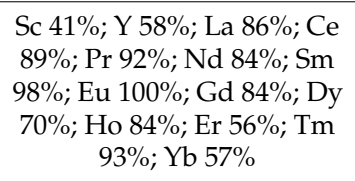 & N/A & [39] \\
\hline $\begin{array}{l}\text { Fire Clay coal } \\
\text { middlings } \\
\text { WK No. } 13 \text { middlings } \\
\text { Lower Kiitanning } \\
\text { middlings }\end{array}$ & $\begin{array}{l}\text { Flotation, magnetic } \\
\text { separation with } \\
\text { acid leaching }\end{array}$ & $\mathrm{HNO}_{3}, \mathrm{pH} 0,75^{\circ} \mathrm{C}$ & $\begin{array}{c}\text { Fire Clay coal middlings } \\
\text { Sc 39\%; La 84\%; Ce 88\%; Pr } \\
\text { 89\%; Nd 88\%; Sm 92\%; Eu } \\
\text { 77\%; Gd 85\%; Tb 0\%; Dy } \\
\text { 78\%; Ho 82\%; Er 48\%; Tm } \\
\text { 71\%; Yb 51\%; Y 64\%; Lu } \\
\text { 91\% } \\
\text { WK No. } 13 \text { middlings } \\
\text { Sc 29\%; La 15\%; Ce 21\%; Pr } \\
\text { 20\%; Nd 31\%; Sm 47\%; Eu } \\
\text { 50\%; Gd 58\%; Tb 63\%; Dy } \\
\text { 0\%; Ho 0\%; Er 34\%; Tm } \\
\text { 29\%; Yb 35\%; Y 47\%; Lu } \\
\text { 45\% } \\
\text { Lower Kiitanning } \\
\text { middlings } \\
\text { Sc 54\%; La 27\%; Ce 28\%; Pr } \\
\text { 79\%; Nd 25\%; Sm 49\%; Eu } \\
\text { 41\%; Gd 57\%; Tb 54\%; Dy } \\
\text { 0\%; Ho 0\%; Er 10\%; Tm } \\
\text { 26\%; Yb 40\%; Y 40\%; Lu } \\
\text { 65\% }\end{array}$ & $\mathrm{N} / \mathrm{A}$ & [38] \\
\hline- & $\begin{array}{l}\text { Sieving, alkali-acid } \\
\text { leaching } \\
\text { Acid leaching with } \\
\text { ion exchange } \\
\text { Acid leaching with } \\
\text { ion exchange }\end{array}$ & $\begin{array}{c}\mathrm{Na}_{2} \mathrm{CO}_{3}, \mathrm{HCl}, \mathrm{HNO}_{3} \\
\mathrm{HNO}_{3} \text {, tributyl phosphate, } \\
\text { kerosene } \\
\mathrm{HNO}_{3} \text {, tributyl phosphate, } \\
\text { kerosene }\end{array}$ & - & - & [58] \\
\hline $\begin{array}{l}\text { Fly ash from the } \\
\text { Luzhou } \\
\text { power plant, China }\end{array}$ & $\begin{array}{c}\text { Acid leaching } \\
\text { Basic-acid leaching }\end{array}$ & $\begin{array}{c}8 \mathrm{M} \mathrm{HCl}, 20: 1,80^{\circ} \mathrm{C}, 6 \mathrm{~h} \\
1: 40 \% \mathrm{NaOH}, 10: 1,150^{\circ} \mathrm{C}, \\
2 \mathrm{~h}(\text { silica removal } 41.1 \%) \\
2: 8 \mathrm{M} \mathrm{HCl}, 30: 1,80^{\circ} \mathrm{C}, 2 \mathrm{~h}\end{array}$ & $\begin{array}{l}32.36 \% \text { REY } \\
88.15 \% \text { REY }\end{array}$ & $\begin{array}{l}\text { Of }>70 \% \text { amorphous } \\
\text { glass and }<30 \% \\
\text { mineral phases } \\
\text { made-up of mullite, } \\
\text { quartz and iron oxides }\end{array}$ & [48] \\
\hline $\begin{array}{c}\text { Coal ash samples } \\
\text { from major U.S. coal } \\
\text { basins } \\
\text { Appalachian-App, } \\
\text { Illinois-IL, Powder } \\
\text { River basin- PRB }\end{array}$ & $\begin{array}{l}\text { Acid leaching } \\
\text { Alkaline- acid } \\
\text { leaching } \\
\text { Alkaline leaching } \\
\text { with } \mathrm{CaO}\end{array}$ & $\begin{array}{c}12 \mathrm{M} \mathrm{HCl}, 10: 1,85^{\circ} \mathrm{C}, 4 \mathrm{~h} \\
6.25 \mathrm{M} \mathrm{NaOH}, 2 \mathrm{M} \mathrm{HCl} \\
\text { (diluting solution), } 10: 1,85^{\circ} \\
\mathrm{C}, 4 \mathrm{~h} \\
6.25 \mathrm{M} \mathrm{NaOH}+0.89 \mathrm{M} \\
\mathrm{CaO}, 2 \mathrm{M} \mathrm{HCl}(\text { diluting } \\
\text { solution), } 100: 1,85^{\circ} \mathrm{C}, 4 \mathrm{~h}\end{array}$ & $\begin{array}{l}\text { APP: } 57 \% \text { REE } \\
\text { IL: } 43 \% \text { REE } \\
\text { PRB: } 98 \% \text { REE } \\
\text { APP: } 86 \% \text { REE } \\
\text { IL: } 64 \% \text { REE } \\
\text { PRB: } 49 \% \text { REE } \\
\text { APP: } 49 \% \text { REE } \\
\text { IL: } 47 \% \text { REE } \\
\text { PRB: } 25 \% \text { REE }\end{array}$ & $\begin{array}{c}\text { Appalachian: } \\
\mathrm{SiO}_{2} \text { 52.1-57.4\%; } \mathrm{Al}_{2} \mathrm{O}_{3} \\
26.5-33.1 \% ; \mathrm{Fe}_{2} \mathrm{O}_{3} \\
5.7-14.1 \% ; \mathrm{CaO} 1.3-4 \% \text {; } \\
\mathrm{MgO} 0.85-1.19 \% \\
\text { Powder River basin: } \\
\mathrm{SiO}_{2} 29.5-39.2 \% ; \mathrm{Al}_{2} \mathrm{O}_{3} \\
15.3-22.5 \% ; \mathrm{Fe}_{2} \mathrm{O}_{3} \\
4.4-6 \% ; \mathrm{CaO} \\
22.4-33.6 \% ; \mathrm{MgO} \\
4.2-7.8 \% \\
\mathrm{IL:} \\
\mathrm{SiO}_{2} 37.5-48.5 \% ; \mathrm{Al}_{2} \mathrm{O}_{3} \\
16.5-23.1 \% ; \mathrm{Fe}_{2} \mathrm{O}_{3} \\
22.2-26.4 \% ; \mathrm{CaO} \\
1.87-13 \% ; \mathrm{MgO} .88-1 \%\end{array}$ & [19] \\
\hline
\end{tabular}


Table 4. Cont.

\begin{tabular}{|c|c|c|c|c|c|}
\hline REE Source & Method & Leaching Conditions & REE Recovery & Ash Composition & Ref. \\
\hline $\begin{array}{c}\text { Coal ash samples } \\
\text { from major U.S. coal } \\
\text { basins } \\
\text { Appalachian-App, } \\
\text { Illinois-IL, and } \\
\text { Powder River basin- } \\
\text { PRB }\end{array}$ & $\begin{array}{l}\text { Acid leaching with } \\
\text { roasting }\end{array}$ & $\begin{array}{c}\text { Roasting: } 1: 1, \mathrm{Na}_{2} \mathrm{O}_{2}, \\
\mathrm{CaSO}_{4}, \mathrm{CaO}, \mathrm{Na}_{2} \mathrm{CO}_{3}, \\
\mathrm{NaOH}, 450{ }^{\circ} \mathrm{C}, 0.5 \mathrm{~h} \\
\text { Leaching: } \\
1 \text { and } 2 \mathrm{M} \mathrm{HNO}_{3}\end{array}$ & $\begin{array}{c}\mathrm{Na}_{2} \mathrm{O}_{2} \\
\text { App: } 55-105 \% \\
\text { IL: } 104 \% \\
\text { PRB: } 108 \% \\
\text { NaOH } \\
\text { App: } 65-98 \% \\
\text { IL: } 104 \% \\
\text { PRB: } 108 \% \\
\text { CaO } \\
\text { App: } 11-35 \% \\
\text { IL: } 19 \% \\
\text { PRB: } 108 \% \\
\text { Na }{ }_{2} \mathrm{CO} 3 \\
\text { App: } 5-31 \% \\
\text { IL: } 15 \% \\
\text { PRB: } 104 \% \\
\text { CaSO } \\
\text { App: } 5-40 \% \\
\text { IL: } 21 \% \\
\text { PRB: } 138 \% \\
\left.\text { (NH }{ }_{4}\right)_{2} \mathrm{SO}{ }_{4} \\
\text { App: } 10-50 \% \\
\text { IL: } 22 \% \\
\text { PRB: } 110 \%\end{array}$ & $\begin{array}{c} \\
\\
\\
\\
\text { Appalachian: } \\
\mathrm{SiO}_{2} 54-57 \% ; \mathrm{Al}_{2} \mathrm{O}_{3} \\
28.4-33 \% ; \mathrm{Fe}_{2} \mathrm{O}_{3} \\
\text { 5.7-10.9\%; } \mathrm{CaO} 1.3-4 \% \\
\mathrm{Illinois:} \\
\mathrm{SiO}_{2} 48.5 \% ; \mathrm{Al}_{2} \mathrm{O}_{3} \\
23.1 \% ; \mathrm{Fe}_{2} \mathrm{O}_{3} 22.2 \% \\
\mathrm{CaO} 1.89 \% \\
\mathrm{Powder} \mathrm{River}^{2} \\
\text { basin:SiO } 38.3 \% \\
\mathrm{Al}_{2} \mathrm{O}_{3} 22.5 \% ; \mathrm{Fe}_{2} \mathrm{O}_{3} \\
5.2 \% ; \mathrm{CaO} 22.9 \%\end{array}$ & [11] \\
\hline
\end{tabular}

For REEs recovery from fly ashes were used many methods, like for instance acid leaching with $\mathrm{HCl}, \mathrm{HNO}_{3}, \mathrm{H}_{2} \mathrm{SO}_{4}$, and alkaline roasting leading to enhancement of $\mathrm{REE}$ leaching. However, acid-or alkaline- based methods are energy-intensive and have high reagent consumption [11,59-61]. To improve the efficiency of leaching processes some modifications can be introduced, like for instance roasting with various reagents, selection of appropriate parameters, like flux-to-ash ratio, type of reagents, $\mathrm{pH}$, temperature, time, the roasting temperature, etc. [11].

For instance, Kashiwakura et al. used the dilute $\mathrm{H}_{2} \mathrm{SO}_{4}$ as the leaching reagent and have found that the REE recovery depended on many parameters, like the type of the original coal and combustion conditions, including temperature, oxygen concentration, time, and cooling rate of coal fly ash particles and of course the conditions of leaching process (concentration and temperature of solvent) [53]. They have optimized the parameters (agitation and acid leaching in $80{ }^{\circ} \mathrm{C}$ during $2 \mathrm{~h}$ ) and obtained REE recovery from $62 \%$ to $114 \%$. Cao et al. found that the high leaching efficiency is obtained after the destruction of glassy phase, in which REEs are mainly contained. They have stated that $\mathrm{HCl}$ was more effective ( $80 \%$ efficiency), in comparison with $\mathrm{H}_{2} \mathrm{SO}_{4}$. It could be caused by precipitation of, e.g., $\mathrm{CaSO}_{4}$, which could cover the particle surfaces. This could prevent the diffusion of $\mathrm{H}^{+}$into the particle and decrease of the REEs leaching. Cao et al. examined the influence of various parameters on the extraction process and found that acid concentration, reaction time, temperature, and liquid/solid ratio have huge impact on leaching efficiency, while the influence of stirring speed was negligible. After optimization of process conditions (3 $\mathrm{M} \mathrm{HCl}$, liquid-solid ratio 10:1, $200 \mathrm{rpm}, 60{ }^{\circ} \mathrm{C}$, and $120 \mathrm{~min}$ ) was obtained $71.9 \%, 66.6 \%$, and $61.9 \%$ of leaching efficiency for $\mathrm{La}, \mathrm{Ce}$, and $\mathrm{Nd}$, respectively [55].

Depending on the ash composition and the reagents used in the method of acid-base leaching of REE from coal fly ashes, we can have various reactions.

Examples of leaching reactions of main coal fly ash components during the acidic version of leaching with for instance $\mathrm{HCl}$ could be presented as:

$$
\begin{gathered}
\mathrm{Al}_{2} \mathrm{O}_{3}+6 \mathrm{HCl} \rightarrow 2 \mathrm{AlCl}_{3}+3 \mathrm{H}_{2} \mathrm{O} \\
\mathrm{Fe}_{2} \mathrm{O}_{3}+6 \mathrm{HCl} \rightarrow 2 \mathrm{FeCl}_{3}+3 \mathrm{H}_{2} \mathrm{O} \\
\mathrm{CaO}+2 \mathrm{HCl} \rightarrow \mathrm{CaCl}_{2}+\mathrm{H}_{2} \mathrm{O}
\end{gathered}
$$


However, in the case of the reaction between $\mathrm{REE}_{2} \mathrm{O}_{3}$ and $\mathrm{HCl}$ :

$$
\mathrm{REE}_{2} \mathrm{O}_{3}+6 \mathrm{HCl} \rightarrow 2 \mathrm{REECl}_{3}+3 \mathrm{H}_{2} \mathrm{O}
$$

When the REE are present in monazite (phosphate mineral), leaching with $\mathrm{H}_{2} \mathrm{SO}_{4}$ can be used:

$$
2 \mathrm{REEPO}_{4}+3 \mathrm{H}_{2} \mathrm{SO}_{4} \rightarrow(\mathrm{REE})_{2}\left(\mathrm{SO}_{4}\right)_{3}+6 \mathrm{H}^{+}+2 \mathrm{PO}_{4}{ }^{3-}
$$

However, the reaction with concentrated $\mathrm{NaOH}$ would be more suitable, because of the possibility to use a byproduct $\mathrm{Na}_{3} \mathrm{PO}_{4}$ as a fertilizer:

$$
\mathrm{REEPO}_{4}+3 \mathrm{NaOH} \rightarrow \mathrm{REE}(\mathrm{OH})_{3}+\mathrm{Na}_{3} \mathrm{PO}_{4}
$$

To perform the alkaline leaching or improve the acid leaching by the introduction of alkali treatment could be used for instance $\mathrm{NaOH}$ (could cause a conversion of REE minerals to more leachable forms (reaction 8), destruction of the aluminosilicate phase, and liberation of REE-bearing particles):

$$
\begin{gathered}
\mathrm{SiO}_{2}+2 \mathrm{NaOH} \rightarrow \mathrm{Na}_{2} \mathrm{SiO}_{3}+\mathrm{H}_{2} \mathrm{O} \\
\mathrm{Al}_{2} \mathrm{O}_{3}+2 \mathrm{NaOH} \rightarrow 2 \mathrm{NaAlO}_{2}+\mathrm{H}_{2} \mathrm{O} \\
\mathrm{Al}_{2} \mathrm{O}_{3} \cdot 2 \mathrm{SiO}_{2}+6 \mathrm{NaOH} \rightarrow 2 \mathrm{NaAlO}_{2}+2 \mathrm{Na}_{2} \mathrm{SiO}_{3}+3 \mathrm{H}_{2} \mathrm{O} \\
\mathrm{Fe}_{2} \mathrm{O}_{3}+2 \mathrm{NaOH} \rightarrow 2 \mathrm{NaFeO}_{2}+\mathrm{H}_{2} \mathrm{O} \\
\mathrm{REE}_{2} \mathrm{O}_{3}+2 \mathrm{NaOH} \rightarrow 2 \mathrm{NaREEO}_{2}+\mathrm{H}_{2} \mathrm{O}
\end{gathered}
$$

Nugroho et al. worked with coal fly ashes rich in $\mathrm{Fe}_{2} \mathrm{O}_{3}$, which were characterized by reduced effectiveness of REE recovery. That is why they have firstly separated iron oxides (compete with REE during the acid leaching) and after this step recovered REE. This team has used particle size (grain size of 400 mesh) and magnetic (4300 Gauss) separation, receiving in the first step almost $26 \%$ of iron recovery [62]. In turn, Lin et al. separated iron oxides from ashes using dry magnetic separation and found that iron content in magnetic fractions increases with a rise of magnetic field strength. While REE bonded with aluminosilicate phase (non-iron minerals) are enriched in non-magnetic fractions. This physical separation was combined with 10-cycle hydrothermal alkaline treatment, using $\mathrm{NaOH}\left(5 \mathrm{M}\right.$, ratio of $1: 20,100{ }^{\circ} \mathrm{C}$, and $2 \mathrm{~h}$ ), which resulted in REE enrichment by $170 \%$ [57]. In turn, Wang et al. tested the REE extractability using the alkaline-acid ( $\mathrm{NaOH}-\mathrm{HCl})$ combined sequential leaching method. After optimization of experimental conditions, like temperature, time, reagent concentration, and liquid/solid ratio they have removed $41 \%$ of active silica and enriched REE in 39\% using $\mathrm{NaOH}$ leaching and in the second step after desilication over $88 \%$ of REE recovery was achieved [48].

As it was stated before, a very important factor in REE recovery from coal fly ashes is their composition, geochemical characteristics, and its relation to extractability of REEs. Namely, the presence of calcium could lead to the creation of calcium-silicates and zeolites, and this in turn can destabilize and decrease REE leaching from coal fly ash [19,63-65]. However, it could be also observed the opposite situation when the presence of calcium enhanced the REE recovery. These two different situations could be caused by two different sources of calcium (from the ash or added $\mathrm{CaO}$ ). It was observed that under strongly acidic conditions, REE are leached in a higher amount. While, under alkaline conditions, calcium silicates may be created, which could adsorb the leached REE or prevent their further leaching. An alternative could be the addition of $\mathrm{Ca}^{2+}$ instead of $\mathrm{CaO}$. These $\mathrm{Ca}^{2+}$ ions (in the form of $\mathrm{CaCl}_{2}$ and $\mathrm{CaSO}_{4}$ salts) allow one to keep silica in solution due to increased ionic strength $[19,66,67]$. So, the future research should go in the direction to keep silica in the dissolved form during the leaching process in alkaline conditions. Additionally, the addition of $\mathrm{MgO}$ during the REE leaching has not shown the appropriate efficiency, because of magnesium silicates formation. The next problem will be the leaching of other 
metals along with the REEs and the influence of leachate composition on further processing to obtain REEs concentrates. Thus, further separation processes will require appropriate selectivity (trace element removal or immobilization), considering the fact that other metal cations have much higher concentrations [19]. Additionally, Maraghech et al. found that, in the case of acid leaching of fly ash with a high content of alkali metals, the time of the process and acid consumption can be reduced. On the other hand, the alkaline leaching of ashes with a low content of alkali metals was more effective [65].

Taggart et al. analyzed the influence of origin and composition of fly ashes on REE recovery using $\mathrm{HNO}_{3}$ leaching. However, the nitric acid leaching proved to be not very efficient ( $44 \%$ recovery), even after an increase of temperature and usage of concentrated acid $\left(15 \mathrm{M} \mathrm{HNO}_{3}, 85-90^{\circ} \mathrm{C}\right)$. Only after introduction of sintering with $\mathrm{Na}_{2} \mathrm{O}_{2}$ even using the $\mathrm{HNO}_{3}$ with lower concentration $\left(4 \mathrm{M} \mathrm{HNO}_{3}\right)$, greater REE recovery was obtained (>80\%). So, the pretreatment with an alkaline agent would be an effective procedure to release of the REEs without usage of very strong acids (HF). Taggart et al. has continued earlier research using various reagents, like $\mathrm{CaO}, \mathrm{Na}_{2} \mathrm{CO}_{3}, \mathrm{CaSO}_{4},\left(\mathrm{NH}_{4}\right)_{2} \mathrm{SO}_{4}$, and $\mathrm{NaOH}$, which are less expensive alternatives to $\mathrm{Na}_{2} \mathrm{O}_{2}$. Of course, the effectiveness of this sintering pretreatment method depended mainly on the composition of examined ashes. For instance, the high Ca-oxide content fly ashes are more susceptible to acid leaching, because the ash particles are more soluble and that directly influences REE extraction. In turn, in the case of ashes with Ca-Fe-enriched glass phase the acid extracts are richer in REE. It could be caused by alkaline roasting already during their combustion process. That is why they are more sensitive to leaching and do not need the pretreatment with alkali reagents. In the case of another type of fly ashes the pretreatment step is necessary. So, the appropriate method of REE recovery should be properly matched to coal fly ash characteristics. Taggart et al. found that $\mathrm{NaOH}$ roasting was as effective as using $\mathrm{Na}_{2} \mathrm{O}_{2}$, especially after optimization of experimental conditions, like the flux/ash ratio (decrease to factor 6 still maintained extraction efficiency over $50 \%$ ), acid concentration and roasting temperature (over the melting point) [11].

Based on above mentioned data, it could be seen that for acidic leaching were used various acids, like: $\mathrm{HCl}, \mathrm{H}_{2} \mathrm{SO}_{4}$, and $\mathrm{HNO}_{3}$ with a concentration ranging from 3 to $12 \mathrm{M}$, at a temperature of $30-85{ }^{\circ} \mathrm{C}$ and during $2 \mathrm{~h}$ to 5 days, obtaining the recovery from 8 to $114 \%$. The efficiency of the applied method was largely dependent on the temperature (optimal increased by approximately $80^{\circ} \mathrm{C}$ ), but also on the type of acid, and above all on the physicochemical composition of the ash. The leaching efficiency of used acids was different, which could be caused by the existence of silica and its possible negative impact on the REEs leaching due to the adsorption of silicates [11,68]. It was also stated that ashes with a higher $\mathrm{CaO}$ content were characterized by a greater leachability of REE.

In the case of the alkaline leaching, $\mathrm{NaOH}$ was used in the concentration range from 5 to $6.25 \mathrm{M}$, at room temperature to $85^{\circ} \mathrm{C}$ and during $4 \mathrm{~h}$ to 5 days. The highest extraction of REE (49-86\%) was obtained for the concentration of $6.25 \mathrm{M}$, at $85^{\circ} \mathrm{C}$, during $4 \mathrm{~h}$ and in the case of ashes with a higher $\mathrm{Fe}_{2} \mathrm{O}_{3}$ content. Although this method was much less used than acid leaching. To increase its efficiency, attempts were made to introduce additives such as $\mathrm{CaO}$ (unfortunately it lowered the recovery) and combined with $\mathrm{HCl}$ leaching, which increased the recovery to $88 \%$. However, the greatest efficiency was achieved by introducing magnetic separation and sieving prior to the alkaline leaching step.

The efficiency of acid leaching methods also could be increased by combining with physical methods such as flotation, size, and magnetic separation, achieving a recovery of $92-108 \%$. The second method was the roasting with alkali metal compounds such as $\mathrm{Na}_{2} \mathrm{O}_{2}$ and $\mathrm{NaOH}$ beforehand. Here, too, the composition of ashes, especially rich in $\mathrm{CaO}$ and $\mathrm{Fe}_{2} \mathrm{O}_{3}$, played a role. However, when looking for optimal process conditions, one should consider both economic and ecological considerations. It is going about the reduction of used reagents and energy. Therefore, these factors should be considered in further research.

There are also some methods for recovery of REE from coal fly ashes already patented. Like, for instance in US Patent No. 4649031 (800-1200 ${ }^{\circ} \mathrm{C}, \mathrm{HCl}$, REE recovery 92\%), 
the authors have reported method consisting of few stages, namely reduction of grain size, digestion with water, then with dilute aqueous acid solution, separation of phases and isolation of REE from liquid phases. However, unfortunately, this method is not appropriate for the recovery of individual elements from the mixed solution. Next US Patent No. $0287653 \mathrm{~A} 1$ used a mineral acid $\left(\mathrm{HNO}_{3}\right)$ at $90^{\circ} \mathrm{C}$, which were later mixed with an organic solution (tributylphosphate and kerosene) and then with water, from which REE were recovered using ion exchange process. The third US Patent No. 8968688 was based on the same method but was preceded by magnetic separation (magnetic and non-magnetic fractions). Unfortunately, ion exchange method has removed also other metals from the solution, and it needs to be optimized to improve the REEs recovery [58]. However, most of the presented patents did not contain information on the amount of REE recovery.

\subsection{REE Recovery Methods from Obtained Leachates}

As it was mentioned above during the leaching of elements from coal fly ash were used strong acids like for instance $\mathrm{HCl}, \mathrm{HNO}_{3}, \mathrm{H}_{2} \mathrm{SO}_{4}$, or alkalines, like $\mathrm{NaOH}$, which seems to be quite efficient in some cases. However, such leachates are characterized by extreme $\mathrm{pH}$ and complex composition (major elements, like $\mathrm{Si}, \mathrm{Ca}, \mathrm{Fe}, \mathrm{Al}, \mathrm{Na}$, and $\mathrm{Mg}$, which have much higher concentrations than REEs) [69]. To solve that problem some conventional, but also innovative techniques were proposed. From chemical methods of REE recovery were used adsorption on special adsorbents (double layered hydroxide, activated carbon, or alginic acid) [70-74], ion exchange [35,68], and chemical precipitation [69]. However, these chemical methods have some limitations, like high energy consumption and application of huge amounts of chemical reagents, which is associated with high environmental and operational costs. To solve this problem, membrane techniques, biological methods, ionic liquids, and chelating reagents were proposed for REE separation from leaching solutions. Most effective techniques for the recovery of REE from leachate solutions use their presence in the form of trivalent ions $\mathrm{REE}^{3+}$, which form, for example, characteristic complexes with complexing or chelating agents, react with carrier molecules or are used as template ions in creating ion imprinted polymers (IIPs). Unlike the rest of the matrix ions in the separated solution.

\subsubsection{Membrane Methods for REE Recovery from Leachates}

During the research, several different membrane methods were proposed, such as reverse osmosis (RO), nanofiltration (NF), emulsification liquid membrane (ELM), and hollow fiber liquid membranes (HFLM), used for REE recovery. Basic data on exemplary membrane techniques used for REE recovery from solutions are presented in Table 5.

Table 5. Summary of data on membrane methods for REE recovery.

\begin{tabular}{|c|c|c|c|c|}
\hline REE Source & Membrane & Conditions & REE Recovery & Ref. \\
\hline $\begin{array}{l}\text { Synthetic mixture of REE } \\
\text { salts }\end{array}$ & $\begin{array}{l}\text { supported liquid membranes for } \\
\text { RO: } \\
\text { di(2-ethylhexyl) phosphoric acid } \\
\text { diethylenetriaminepent-aacetic }\end{array}$ & $\begin{array}{l}\text { solution of REE content: } 0.01 \\
\text { g mol/L } \\
\mathrm{pH} 2\end{array}$ & $\begin{array}{l}\text { Nd 93\%; Ho 99.89\%; Y 99.02\%; Gd } \\
\text { 99.90\%; Sm 99.95\%; La 99.67\% }\end{array}$ & [75] \\
\hline Seawater sample & $\begin{array}{c}\text { 8-hydroxyquinoline } \\
\text { immobilized } \\
\text { PAN hollow fiber membrane }\end{array}$ & 24 h, pH 6 & $\begin{array}{c}\text { Y 98-102\%; La 98-104\%; Ce } \\
\text { 94.6-107\%; Pr 97-104\%; Nd } \\
\text { 94-104\%; Sm 96-105\%; Eu } \\
\text { 94-100\%; Gd 91-102\%; Tb } \\
\text { 94-102\%; Dy 92-107\%; Ho } \\
\text { 92-104\%; Er 97-106\%; Tm } \\
\text { 95-102\%; Y 97-107\%; Lu 95-106\% }\end{array}$ & [76] \\
\hline
\end{tabular}


Table 5. Cont.

\begin{tabular}{|c|c|c|c|c|}
\hline REE Source & Membrane & Conditions & REE Recovery & Ref. \\
\hline Synthetic leachate & $\begin{array}{l}\text { nanofiltration membrane } \\
\qquad(\mathrm{NF}-300)\end{array}$ & $\begin{array}{c}\text { pressure: } 2-10 \text { bar } \\
\text { cross flowrate: } 4-16 \mathrm{~L} \\
\text { min }^{-1} \\
\text { acid solution } \\
\text { initial feed concentration } \\
\text { of } 10 \text { and } 100 \mathrm{mg} \mathrm{L}^{-1} \\
\text { PrCl } \\
\text { complexation step } \\
\text { EDTA } \\
\text { DTPA pH }(2-10)\end{array}$ & $\begin{array}{c}\text { Pr: } 89 \% \\
\text { Pr: } 89.07 \text { and } 84.20 \% \\
\text { Pr: } 99.28 \% \\
\text { Pr: } 99.30 \%\end{array}$ & [77] \\
\hline $\begin{array}{c}\text { Simulated leachate } \\
\text { of six } \operatorname{REEs}\left(\mathrm{Y}^{3+}, \mathrm{Nd}^{3+},\right. \\
\left.\mathrm{Dy}^{3+}, \mathrm{Er}^{3+}, \mathrm{Eu}^{3+}, \mathrm{Tb}^{3+}\right)\end{array}$ & $\begin{array}{l}\text { MF membranes: PES: } \\
\text { Polyethersulfone; MCE: } \\
\text { Mixed Cellulose Ester; PC: } \\
\text { Polycarbonate } \\
\text { NF membrane: Thin Film } \\
\text { Composite }\end{array}$ & $\begin{array}{l}\text { pressure: } 12 \text { bar, } \mathrm{pH} 3.5 \\
\text { pretreatment step: } \mathrm{pH} 1 \\
\text { and } \mathrm{MF}\end{array}$ & $\begin{array}{c}\text { removal of } \mathrm{Fe}-98 \%, \mathrm{Si}-41 \% \text {, } \\
\text { and } \mathrm{Al}-50 \% \\
\mathrm{NF}>90 \% \mathrm{REE}\end{array}$ & [69] \\
\hline Synthetic REE solution & $\begin{array}{c}\text { Carrier: Cyanex272, } \\
\text { Surfactant: ECA-4360, } \\
\text { Span80, } \\
\text { Tween } 80 \\
\text { ELM technique }\end{array}$ & - & $>99 \%$ REEs & [78] \\
\hline Synthetic REE solution & $\begin{array}{l}\text { Carrier: Cyanex } 272, \\
\text { Surfactant: Span } 85 \\
\text { ELM technique }\end{array}$ & $\begin{array}{l}\text { Multi-walled carbon } \\
\text { nanotubes applied to } \\
\text { stabilize the ELM }\end{array}$ & $92.05 \% \mathrm{Gd}^{3+}$ & [79] \\
\hline Synthetic REE solution & $\begin{array}{c}\text { Carrier: Cyanex272, } \\
\text { Membrane Solvent: } \\
\text { Kerosene, } \\
\text { Membrane material: PP } \\
\text { HFLM process }\end{array}$ & $\begin{array}{l}\text { 6-cycle operation with } \\
\text { cumulative extraction }\end{array}$ & $91.7 \% \operatorname{Pr}^{3+}$ & [80] \\
\hline Synthetic REE solution & $\begin{array}{l}\text { Carriers: DNPPA, TOPO } \\
\text { Membrane Solvent: Petrofin } \\
\text { Membrane Material: PP } \\
\text { HFLM process }\end{array}$ & $\begin{array}{l}0.5 \mathrm{~h} \text { via non-dispersive } \\
\text { solvent extraction }\end{array}$ & $>99.9 \% \mathrm{Nd}^{3+}$ & [81] \\
\hline
\end{tabular}

For instance, Shimizu et al. used reverse osmosis on supported liquid membranes, such as di (2-ethylhexyl) phosphoric acid and diethylenetriaminepentaacetic acid to concentrate $\mathrm{Nd}$, obtaining up to $93 \%$ recovery [75]. In turn, Wen et al. used hollow fiber membrane consisting of 8-hydroxyquinoline immobilized onto polyacrylonitrile to concentrate REEs 300 times. Operation of this type of membranes is based on the preferential formation of REE (III) complexes with 8-hydroxyquinoline or di (2-ethylhexyl) phosphoric acid and diethylenetriaminepentaacetic acid (chelating agents) under controlled $\mathrm{pH}$ conditions, over other metals present in the solution (alkaline and alkaline-earth cations). This leads to the separation of the matrix ions and concentration of the REE in the membrane, which can then be recovered by eluting with a suitable solvent, such as $\mathrm{HCl}$ and $\mathrm{HNO}_{3}$ [76].

It was found that nanofiltration technique was appropriate to REE recovery from complex solutions. Especially, due to lower energy consumption (compared to reverse osmosis) and the absence of chelating agents (compared to supported liquid membranes). This technique could be used in major mono- and divalent matrix ions separation from trivalent REEs during the multistep process. Methods based on NF membranes are usually preceded by a stage in which iron, silicon, and aluminum ions (competing ions) are precipitated, which were then separated using the MF technique based on the sieve mechanism, where the optimal $\mathrm{pH}$ and pore, ensuring complete rejection of precipitated particles and maximum REE concentration. The next step was the separation of monovalent ions such 
as $\mathrm{NO}_{3}{ }^{-}, \mathrm{Cl}^{-}$, and $\mathrm{Na}^{+}$from the trivalent REE and concentration of the REE with the use of NF membranes (through the rejection mechanism), the effectiveness of which depended on several parameters. Obviously, the course of this process will be mainly influenced by the transmembrane pressure and the $\mathrm{pH}$ of the solution to be separated. By increasing the pressure, the permeate flux can be increased, but unfortunately by increasing the transport of REE and impurities to the membrane. The influence of this pressure on ion rejection strongly depends on the $\mathrm{pH}$ of the solution, which, by changing the charge of functional groups on the membrane, affects the charge and speciation of the solute, e.g., by lowering the $\mathrm{pH}$, the number of functional groups increases, which leads to a positive zeta potential, which can increase retention metal ions. Therefore, the main tasks are to find the optimal combinations of operating conditions for the concentration of REE in acidic solutions and the separation of monovalent ions. The highest REE rejection was obtained for membranes, which has the combined effect of a low MWCO and a high positive charge (zeta potential) affecting the screening and potential Donnan rejection mechanisms. Murthy et al. stated that the nanofiltration membrane could concentrate the Pr from acid solution with $89 \%$ efficiency [77]. Mutlu et al. stated that the whole process flow depended on the $\mathrm{pH}$ and characteristics of separated solutions. For instance, the decrease of $\mathrm{pH}$ increased the amount of positively charged functional groups and that caused a rise of metal ions retention. That is why the selection of optimal operating conditions for the nanofiltration of complex solutions and separation of REE is a real challenge. Mutlu et al. reached a maximum REE recovery $(>90 \%)$ at the optimum operating conditions of 12 bar and $\mathrm{pH} 3.5$, but only for synthetic leachate. In the case of REEs recovery from real leachates, it will be necessary to study the fouling mechanism and the effect of feed concentration on the process efficiency. However, when NF membranes cannot separate REEs from major components of leachates could be used a pre-NF stage consisting of $\mathrm{pH}$ adjustment and microfiltration. So, the nanofiltration could be an alternative technique for REE recovery from coal fly ash leachates and could play an important role in industrial recovery technologies in the future [69]. In turn, Qin et al. used the emulsification liquid membrane (ELM) obtaining over 99\% REE recovery. The principle of ELM membranes operation is based on five possible steps of the coupled transport process. Firstly, REEs diffuse from the feed phase through the boundary layer of the feed-membrane side, then REEs are extracted by carriers at the interface and such created REE-complexes diffuse across the membrane, after that they are dissociated at the interface of the stripping-membrane side and, finally, REE ions are diffused through the boundary of the stripping-membrane side to the stripping phase. The most important role in the ELM separation process plays the carrier, which act like a "shuttle" that carry target species (REEs) from the feed to permeate side of the membrane and is a key factor in their preferential adsorption in the membrane. The typical ELM system contains of few components, like carrier, surfactant, diluent, feed, and stripping solution.

The separation of REE ions using for instance this ELM or HFLM system is based on the reaction between REE ions and carrier molecules $(\mathrm{HR})_{2}$ :

$$
\mathrm{REE}^{3+}+3(\mathrm{HR})_{2}=\mathrm{REE}\left(\mathrm{HR}_{2}\right)_{3}+3 \mathrm{H}^{+}
$$

Qin et al. created system based on Cyanex272, as a carrier and ECA-4360, Span80, as surfactants [78]. However, despite their numerous advantages, they also have disadvantages related to instability problems, like membrane leakage and emulsion swelling, that require appropriate modifications (introduction of more appropriate surfactants or multi-wall nanotubes). That is why Davoodi-Nasab et al. introduced another type of emulsion nanofluids membrane (carrier: Cyanex272, surfactant: Span85), modified by multiwalled nanotubes for $\mathrm{Gd}^{3+}$ extraction. The introduction of multi-walled carbon nanotubes (MWCNTs) has stabilized the ELMs and increased the efficiency of theses membranes, ultimately allowing one to achieve $92.05 \%$ Gd recovery [79].

The next type of membranes used for REE recovery were hollow fiber liquid membranes (HFLM). 
The principle of operation of HFLM membranes is similar to the ELM, with the difference that feed solution will flow through the lumen of the fibers, while the REE selective carriers in the organic phase will flow outside the fibers either in a cocurrent or countercurrent flow mode. REE ions will diffuse into the organic phase through the micropores on the fibers.

It should be noted that two HFLM modules could be linked one after the other to realize the extraction and stripping of separate REEs, like for instance $\mathrm{Pr}^{3+}, \mathrm{Sm}^{3+}$, and $\mathrm{Y}^{3+}$. Wannachod et al. applied such a membrane type (carrier: Cyanex272, membrane solvent: Kerosene, membrane material: PP) for praseodymium recovery, obtaining finally 91.7\% [80]. While, Ambare et al. have used HFLM consisting of the following components, like: DNPPA and TOPO, as carriers, Petrofin as the membrane solvent, and PP as the membrane material. They have achieved over $99.9 \% \mathrm{Nd}^{3+}$ in $0.5 \mathrm{~h}$ via non-dispersive solvent extraction [81]. In conclusion, HFLMs perform highly efficient transport and separation behavior with high interfacial area per volume and easy assembly module. Main future research directions may be the synthesis of highly selective and permeative membrane materials and novel breakthroughs in inorganic membranes with thinner thickness, smaller pores, and narrow pore distributions. Considering the extremely similar physical and chemical properties between adjacent REEs, the organic liquid membrane phases should be developed with more specific selectivity for REEs. An appropriate solution could be membranes based on ion-imprinted polymers (IIPs), which will have the appropriate selectivity and affinity to individual REEs. The mechanism of action of these membranes is based on the assumption that the target template ions will be recognized and adsorbed by the imprinted sites on the membrane, while the interfering ions will not be selected by the specific imprinted sites and passed through the membrane. For instance, Zheng et al. had synthesized $\mathrm{Nd}^{3+}$-imprinted mesoporous film and applied to separate $\mathrm{Nd}^{3+}$ from $\operatorname{Pr}^{3+}$. While the Liu et al. prepared another interconnected 3D macroporous structure $\mathrm{Dy}^{3+}$-imprinted membrane and used it for the selective separation of $\mathrm{Dy}^{3+}$ from $\mathrm{Tb}^{3+}$ and $\mathrm{Fe}^{3+}[82,83]$. IIPs are still used rarely for REE separation, because of problems in the polymerization methods, porous structure forming, permselectivity, and recycling properties, which are setting higher demands for membrane applications. However, preliminary results show that the use of IIPs would be ideal for separating individual REEs from solutions.

So, it can be seen that all the applied membranes allowed one to obtain REE enrichment above $90 \%$ (Table 5), especially in the case of techniques based on NF and ELM and HFLM (almost $100 \%$ ). However, only some of the membrane techniques, such as multistage HFLM or based on IIPs, will produce individual REEs, unlike most of them where REEs concentrates were obtained as a mixture. Some modifications were also used, such as combination with an additional MF stage, or complexation with EDTA or DTPA to increase the REE recovery by a few additional \% and to remove elements belonging to the ash matrix, such as Fe, Al, and Si. Thus, membrane techniques make it possible to obtain high yields of REE recovery from extracts produced in the leaching process and represent an alternative to conventional techniques and have a special future potential.

\subsubsection{Biological Methods of REE Recovery}

Bioleaching in comparison with chemical leaching is environmentally friendly, requires less energy, and less consumption of chemical reagents. That is why bioleaching was used for recovery of many metals, such as: $\mathrm{Ni}, \mathrm{Cr}, \mathrm{Zn}, \mathrm{Au}, \mathrm{Cu}$, and $\mathrm{Pb}$ from sulfidic low-grade ores and various industrial solid wastes [84-88]. The mechanism of bioleaching consists of few stages, namely: growing of attached microbes on the mineral surface and then secretion of organic acids, amino acids, peptides, enzyme complexes, lipids, cyanide ions, etc. Of course, the organic acids, such as oxalic, tartaric, citric, and gluconic are the main leaching agents [89]. These acids cause the metal dissolution by proton-promoted dissolution, creation of surface complexes and metal-ligand complexes [90]. Basic data on exemplary biological methods used for REE recovery are presented in Table 6. 
Table 6. Summary of data on the selected biological methods for REE recovery.

\begin{tabular}{|c|c|c|c|c|}
\hline REE Source & Microorganism & Conditions & REE Recovery & Ref. \\
\hline Monazite bearing ore & Acetobacter aceti & $\begin{array}{c}30{ }^{\circ} \mathrm{C}, 6 \mathrm{~h}, 1 \% \text { pulp density, } 50 \\
\mathrm{rpm}\end{array}$ & $0.13 \% \mathrm{Ce} ; 0.11 \% \mathrm{La}$ & [91] \\
\hline Uraniferous Gibbsite ore & $\begin{array}{l}\text { Acidthiobacillus } \\
\text { ferrooxidans }\end{array}$ & 30 cycles & $67.58 \%$ REEs & [92] \\
\hline Monazite & $\begin{array}{c}\text { Aspergillus ficuum } \\
\text { Pseudomonas aeruginosa }\end{array}$ & $\begin{array}{c}30{ }^{\circ} \mathrm{C}, 9 \mathrm{~h}, 0.6 \% \text { pulp density } \\
35^{\circ} \mathrm{C}, 8 \mathrm{~h}, 0.6 \% \text { pulp density, } \\
175 \mathrm{rpm}\end{array}$ & $\begin{array}{l}75.4 \% \text { REEs } \\
63.5 \% \text { REEs }\end{array}$ & [93] \\
\hline Ash-slug waste & $\begin{array}{c}\text { Acidophilic } \\
\text { chemolithotrophic } \\
\text { community }\end{array}$ & $45^{\circ} \mathrm{C}, 10 \mathrm{~h}, 10 \%$ pulp density & $52.0 \%$ Sc; $52.6 \%$ Y; $59.5 \% \mathrm{La}$ & [94] \\
\hline Coal fly ash & Candida bombicola & $\begin{array}{c}28^{\circ} \mathrm{C}, 9 \mathrm{~h}, 16.7 \% \text { pulp density, } \\
180 \mathrm{rpm}\end{array}$ & $67.7 \% \mathrm{Yb} ; 64.6 \% \mathrm{Er} ; 63 \% \mathrm{Sc}$ & [84] \\
\hline $\begin{array}{l}\text { Thorium-uranium } \\
\text { concentrate }\end{array}$ & Aspergillus ficuum & $\begin{array}{c}28^{\circ} \mathrm{C}, 1 \mathrm{~h}, 0.75 \% \text { pulp density, } \\
175 \mathrm{rpm}\end{array}$ & $20 \% \mathrm{La} ; 33 \% \mathrm{Ce} ; 2.51 \% \mathrm{Y}$ & [84] \\
\hline
\end{tabular}

For instance, Muravyov et al. proposed a new biological method used before for metal recovery from low-grade sulphide ores applying bioleaching by acidophilic chemolithotrophic iron- and sulphur-oxidizing microorganisms. However, coal fly ashes do not contain sulphur, which could be used as an energy substrate by microorganisms. That is why the team has proposed elemental sulphur as substrate for microbial oxidation, acid formation, and $\mathrm{pH}$ decrease for REE leaching. The leaching process took ten days $\left(45^{\circ} \mathrm{C}\right.$; initial $\mathrm{pH}, 2.0$, and the coal ash to elemental sulphur ratio, 10:1), by using strains of Acidithiobacillus ferrooxidans, A. thiooxidans, A. caldus, and Sulfobacillus thermosulfidooxidans. The team has obtained recovery: $52.0 \%, 52.6 \%$, and $59.5 \%$ of scandium, yttrium, and lanthanum, respectively [94].

Bioleaching was also introduced to the recovery of REE from: monazite $(75.4 \%$ and $63.5 \%$ of REEs were leached by Aspergillus ficuum and Pseudomonas aeruginosa, respectively) $[84,93]$, thorium-uranium concentrate $(20 \%$ of $\mathrm{La}, 33 \%$ of $\mathrm{Ce}$, and $2.51 \%$ of $\mathrm{Y}$ dissolved by A. ficuum strain) [84,95], uraniferous gibbsite ore (55.1\% of REE was leached by the Acidithiobacillus ferrooxidans strain) [84,92], etc.

C. bombicola strains were used by Park and Liang for recovery of few REEs, like $\mathrm{Yb}$ (67.7\% of leaching efficiency), Er (64.6\% of leaching efficiency), and Sc (63.0\% of leaching efficiency). This study has demonstrated that bioleaching is feasible for leaching metals out of fly ash, but due to some limitations it requires further research [84].

Based on the above mentioned data, it should be concluded that the recovery of REE using biological methods depends mainly on the source of these elements (much higher in the case of ashes and monazite, over 63\%) and on the type of applied microorganisms (the highest with Candida bombicola and Aspergillus ficuum-over 74\%). However, it should be stated that the recovery of REE using the described method is lower than that of the previous methods, but it has some future potential.

\subsubsection{Application of Ionic Liquids and Chelating Reagents in REE Recovery}

The second step after the obtaining of leachate is the separation of REEs. This could be performed using various methods, among others by the application of ionic liquids, which are molten salts, consisting of organic cations in combination with inorganic or organic anions. They can be an alternative for organic reagents in liquid-liquid extraction (for instance in metal separation), because of their excellent extractabilities [44,96-99]. Many studies were performed on application of ILs in metal ions extraction, such as Aliquat 336, used for Fe (III) extraction from chloride leachate of iron ore, [ $\mathrm{N}_{1888}$ ] [SOPAA] used for separation of REEs from chloride solution, etc. [100-103]. Basic data on the exemplary 
methods based on ILs and chelating agents used for REE recovery from solutions are presented in Table 7.

Table 7. Summary of data on selected methods based on ILs and chelating agents for REE recovery.

\begin{tabular}{|c|c|c|c|c|}
\hline REE Source & Used Reagents & Conditions & REE Recovery & Ref. \\
\hline $\begin{array}{l}\text { Coal fly ash, Guizhou } \\
\text { Province (China) }\end{array}$ & $\begin{array}{c}{\left[\mathrm{N}_{1888}\right] \mathrm{Cl}} \\
{\left[\mathrm{P}_{6,6,6,14}\right] \mathrm{Cl}}\end{array}$ & $\begin{array}{l}\text { Acid leaching: } 12 \mathrm{M} \mathrm{HCl}, 200 \\
{ }^{\circ} \mathrm{C}, 9 \mathrm{~h} \\
\text { ILs extraction: } 0.5 \mathrm{~h}, 25^{\circ} \mathrm{C}\end{array}$ & $<10 \%$ & [104] \\
\hline $\begin{array}{l}\text { Coal fly ash, Guizhou } \\
\text { Province (China) }\end{array}$ & $\begin{array}{c}{\left[\mathrm{N}_{1888}\right] \mathrm{Cl}} \\
{\left[\mathrm{N}_{1888}\right][\mathrm{SOPAA}]}\end{array}$ & $\begin{array}{c}\text { Acid leaching: } 12 \mathrm{M} \mathrm{HCl}, 200 \\
{ }^{\circ} \mathrm{C}, 9 \mathrm{~h} \\
\text { ILs extraction: } 0.5 \mathrm{~h}, 25{ }^{\circ} \mathrm{C} \\
\text { Precipitation: } \\
\mathrm{NH}_{4} \mathrm{HCO}_{3} / \mathrm{Na}_{2} \mathrm{C}_{2} \mathrm{O}_{4} \\
\text { solution }\end{array}$ & $>37 \%$ & [104] \\
\hline Synthetic REE solution & {$\left[\mathrm{N}_{1888}\right]\left[\mathrm{CA}_{12}\right]$} & $\begin{array}{l}\text { Initial solution: } 0.16 \mathrm{Y} \text { in } 0.20 \\
\text { mol/L REEs } \\
13 \text { stages of extraction } \\
\text { section, } 8 \text { stages of scrubbing } \\
\text { section and } 5 \text { stages of } \\
\text { stripping section }\end{array}$ & $99.1 \% \mathrm{Y}$ & [101] \\
\hline Lu and Y solution & {$\left[\mathrm{P}_{6,6,6,14}\right][\mathrm{SOPAA}]$} & $\begin{array}{l}5 \text { stages of extraction and } 4 \\
\text { stages of scrubbing sections }\end{array}$ & $\begin{array}{l}\text { Lu (III) separated } \\
\text { from Y(III) }\end{array}$ & [96] \\
\hline Synthetic REE solution & $\begin{array}{l}{\left[\mathrm{A}_{336}\right]\left[\mathrm{CA}_{12}\right]} \\
{\left[\mathrm{A}_{336}\right]\left[\mathrm{CA}_{100}\right]}\end{array}$ & - & $>95 \%$ La (III) & [102] \\
\hline $\begin{array}{l}\text { Thermal } \\
\text { power plant fly ash, Japan }\end{array}$ & $\begin{array}{l}\text { EDTA } \\
\text { EDDS } \\
\text { HIDS }\end{array}$ & $\begin{array}{l}0.15 \mathrm{M} \text { EDTA, } \mathrm{pH} 7,25^{\circ} \mathrm{C} \\
0.01 \mathrm{M} \text { EDTA, } \mathrm{pH} 7,98^{\circ} \mathrm{C}\end{array}$ & $\begin{array}{l}14 \% \mathrm{Ce} \\
18 \% \mathrm{Ce}\end{array}$ & [105] \\
\hline $\begin{array}{c}\text { 50:50 Y/Lu } \\
\text { Y/Yb } \\
\text { Eu/Y mixture }\end{array}$ & $\begin{array}{l}\text { redox-active ligand }[\{2- \\
\left.\left.(\mathrm{tBuN}(\mathrm{O})) \mathrm{C}_{6} \mathrm{H}_{4} \mathrm{CH}_{2}\right\}_{3} \mathrm{~N}\right]^{3-}\end{array}$ & - & $\begin{array}{l}94 \% \mathrm{Y} \\
84 \% \mathrm{Yb} \\
86 \% \mathrm{Eu}\end{array}$ & [106] \\
\hline
\end{tabular}

Most of the articles on the extraction of REEs with ionic liquids concern artificial solutions. However, there are few examples of the use of ILs in the separation of REEs from extracts from the processing of fly ash from coal combustion.

Using this method, the Huang et al. obtained enrichment of $\mathrm{Al}, \mathrm{Fe}$, and $\mathrm{Ca}(94,40$, and 8.7 times). While REEs, like $\mathrm{Nd}, \mathrm{Ce}, \mathrm{La}, \mathrm{Gd}, \mathrm{Tm}, \mathrm{Er}, \mathrm{Lu}, \mathrm{Y}$, and $\mathrm{Yb}$ were recovered in $37.4 \%$. Huang et al. used $\left[\mathrm{N}_{1888}\right] \mathrm{Cl}$ and $\left[\mathrm{P}_{6,6,6,14}\right] \mathrm{Cl}$ for $\mathrm{Fe}$ (III) extraction with almost $100 \%$ efficiency (bond between Fe and quaternary ammonium or phosphorus salt), while for the REE (III) the efficiency was lower than $10 \%$. To obtain better separation between Fe (III) and REE (III) the appropriate acidity was maintained (1-2 mol/L). Additionally, the leaching solution was purified from Fe (III), $\mathrm{Al}$ (III), and Ca (II), through multiple extraction: twice with $\left[\mathrm{N}_{1888}\right] \mathrm{Cl}$ and once with [ $\mathrm{N}_{1888}$ ] [SOPAA]. Finally, the ammonium hydrogen carbonate $\left(\mathrm{NH}_{4} \mathrm{HCO}_{3}\right)$ was used to further remove these ions. After this the REE (III) in the purified solution was precipitated using oxalic acid [104].

Another REE recovery method from coal fly ashes is based on the application of aminopolycarboxylate chelating agents (APCs), such as EDTA, EDDS, and HIDS. It was found that the highest process efficiency was obtained in extraction with EDTA (chelate concentration $0.01 \mathrm{~mol} \cdot \mathrm{L}^{-1} ; \mathrm{pH} 7$ ). The effect of a higher concentration of chelant in the solution $\left(0.05,0.10\right.$, and $\left.0.15 \mathrm{~mol} \cdot \mathrm{L}^{-1}\right)$, increased temperature $\left(40,60,80\right.$, and $\left.98^{\circ} \mathrm{C}\right)$, and ultrasonic irradiation on the increase of extraction efficiency was also examined. It turned out that a chelant concentration of $0.15 \mathrm{~mol} \cdot \mathrm{L}^{-1}$ (until $14 \%$ of Ce) or an increase of the temperature in the range of $60-98{ }^{\circ} \mathrm{C}$ can increase the extraction efficiency (until $18 \%$ of $\mathrm{Ce}$ ). In contrast, the use of ultrasonic irradiation enabled better dissolution of rare metals 
in the chelant solution with minimal chelant concentration and at room temperature (from $1 \%$ to $5 \%$ of Ce) $[84,105]$.

The typical reaction using chelating ligands HL could be expressed as:

$$
\mathrm{REE}^{3+}+3 \mathrm{HL} \rightarrow \mathrm{REE}(\mathrm{L})_{3}+3 \mathrm{H}^{+}
$$

The separation and purification of individual REEs from obtained mixture is difficult because of their chemical similarities. That is why the appropriate separation techniques should be created that will reduce the cost.

Like, for instance Wang et al., who used multistage method based on few bifunctional ILs, like $\left[\mathrm{N}_{1888}\right]\left[\mathrm{CA}_{12}\right]$ for $\mathrm{Y}$ recovery $(99.1 \%)$ and $\left[\mathrm{A}_{336}\right]\left[\mathrm{CA}_{12}\right],\left[\mathrm{A}_{336}\right]\left[\mathrm{CA}_{100}\right]$ for $\mathrm{La}$ recovery (over 95\%).

If it is going about REEs extraction in ILs, there are two possible mechanisms, like cation exchange and neutral mechanism, which is shown by the following reaction:

$$
\mathrm{REECl}_{2}{ }^{+}+\mathrm{Cl}^{-}+\left[\mathrm{N}_{1888}\right][\mathrm{L}] \leftrightarrow\left[\mathrm{N}_{1888}\right] \mathrm{Cl} \cdot \mathrm{REELCl}_{2}
$$

This extraction can be considered as the neutral mechanism combined with ion association. Due to the hydration of $\mathrm{Cl}^{-}$and water in low-acidity media, only one $\mathrm{Cl}^{-}$of $\mathrm{REEECl}_{3}$ maintains ionic properties. The next step after extraction is the stripping process, which in the case of cation exchange system is carried out with the help of high concentration acids. While in the case of the neutral extraction system, water is commonly used as a reagent. The stripping equation in this system can be written as follows:

$$
\left[\mathrm{N}_{1888}\right] \mathrm{Cl} \cdot \mathrm{REELCl}_{2}+\mathrm{H}_{2} \mathrm{O} \leftrightarrow \mathrm{REECl}_{3}+\left[\mathrm{N}_{1888}\right][\mathrm{L}]
$$

Such bifunctional ionic liquids were successfully applied for the separation of yttrium (purity 99.1\%) and lanthanum (purity over 95\%) from highly concentrated REEs solutions (many stages of extraction, scrubbing, and stripping).

In turn, the Schelter et al. introduced a new type of tailored organic compounds: tris (2-tert-butylhydroxylaminato) benzylamine $\left(\mathrm{H}_{3}\right.$ Tri-NOx). They have used differences in the oxidation rates within a series of rare earth compounds containing the redox-active ligand $\left[\left\{2-(t \mathrm{BuN}(\mathrm{O})) \mathrm{C}_{6} \mathrm{H}_{4} \mathrm{CH}_{2}\right\}_{3} \mathrm{~N}\right]^{3-}$ to separate the REE mixture $(94 \% \mathrm{Y}, 84 \% \mathrm{Yb}$, and $86 \% \mathrm{Eu})$ [106].

Based on the above mentioned data, it can be concluded that the use of appropriately selected ionic liquids and multistage extraction allows for the enrichment of REE above 95\% ([N $\left.\left.\mathrm{N}_{1888}\right]\left[\mathrm{CA}_{12}\right],\left[\mathrm{A}_{336}\right]\left[\mathrm{CA}_{12}\right]\left[\mathrm{A}_{336}\right]\left[\mathrm{CA}_{100}\right]\right)$. While, the use of popular chelating compounds, such as EDTA, EDDS, and HIDS, made it possible to obtain only $18 \%$ of Ce enrichment. However, in this case, the reactants were acted upon directly on the fly ash, and not on the synthetic REE mixture. Another solution may be the use of tailored complexing compounds, such as $\mathrm{H}_{3}$ Tri- $\mathrm{NO} x$, which allows for obtaining from $84 \%$ to $94 \%$ of REE enrichment.

\section{Summary and Proposition of Procedure for the Recovery of REEs from Coal Fly Ash}

The authors have presented advantages and disadvantages of methods usually used for REE recovery from coal fly ashes, like physical, acid-alkaline leaching, and techniques for REE separation from obtained leachates. Unfortunately, the application of physical methods of REE recovery (flotation, magnetic separation, or based on size, density, and electrostatic properties) was ineffective, especially for fly ashes [38,39,41]. Of course, to create the most efficient method of REE recovery should be solved several problems, connected with the speciation of REE, composition of fly ash (especially existence of $\mathrm{Ca}$, $\mathrm{Mg}$, and Fe compounds), and the optimization of factors controlling the extractivity of REE. A solution to these problems could be found by comparing and combining results obtained from a few different techniques focusing on REE speciation (ICP-MS, S/TEM-EDX, XRD, 
EPMA, $\mu$ XRF, $\mu$ XANES, SHRIMP-RG, etc.) and their extractivity (sequential acid extraction and leaching) [5].

The next group are methods based on acid and base leaching. In their case, the main factors deciding about the process efficiency are connected with physicochemical characteristics of the ashes, leaching of other metals (in much higher concentrations) along with REE, and the influence of the extract composition on further preparation of the REE concentrate. Unfortunately, they are also characterized by a high consumption of reagents and energy [11,59-61]. Therefore, numerous modifications have been introduced, such as roasting with various reagents, selection of optimal parameters, and removal of $\mathrm{Fe}$ oxides from the ashes, to enhance REE recovery. It was found that the efficiency of acid leaching method was largely dependent on the temperature (optimal increased by approximately $80^{\circ} \mathrm{C}$ ), type of acid, and physicochemical composition of the ash (higher $\mathrm{CaO}$ content caused greater REE leachability) $[19,53]$. The combination with physical methods such as flotation, magnetic, and size separation, allowed one to increase the recovery (92-108\%) [38]. Another modification was alkaline roasting of ashes with compounds such as $\mathrm{Na}_{2} \mathrm{O}_{2}$ and $\mathrm{NaOH}$ [11]. In turn, the alkaline leaching was much less used than acid leaching, maybe because of lower process efficiency (49-86\%) [19]. To increase the REE recovery it was combined with $\mathrm{HCl}$ leaching (recovery $88 \%$ ) and the preliminary stage of magnetic separation and sieving (recovery over 100\%) [57]. Unfortunately, conventional methods, such as adsorption, ion exchange, and precipitation, used to recover REE from the obtained extracts have many limitations [70-73]. Therefore, alternative methods were introduced, such as membrane techniques, biological methods, and methods based on chelating compounds and ionic liquids. The main problems that must be faced in the case of REE recovery is the high complexity of the obtained solutions, extreme $\mathrm{pH}$, and high concentrations of the remaining ash components, extracted along with the REE. It was stated that all applied membranes allowed one to obtain REE enrichment above $90 \%$, especially in the case of techniques based on NF and ELM and HFLM (almost 100\%) [77-81]. To increase the efficiency of this process and extend the life of the membrane were proposed some modifications, such as combination with an additional MF stage, complexation with EDTA or DTPA (increase of REE recovery and removal of $\mathrm{Fe}, \mathrm{Al}$, and $\mathrm{Si}$ ) or introduction of IIPs (separation of individual REEs from mixture) $[69,77,82,83]$. The second group are biological methods based on bioleaching with the help of microorganisms. It was stated, that REE recovery depended mainly on the source of these elements (higher from of ashes and monazite, over $63 \%$ ) and on the type of applied microorganisms (the highest with Candida bombicola and Aspergillus ficuum - over 74\%) [84,93]. However, these processes are less efficient than other techniques, but are environmentally friendly. The next method is based on the use of ionic liquids. It was stated that the use of appropriately selected ionic liquids and multistage extraction allows for enrichment of REE above 95\% [101,102]. While, the use of popular chelating compounds, such as EDTA, EDDS, and HIDS, made it possible to obtain small REE recovery ( $18 \%$ of Ce) [105]. Another solution may be the use of tailored complexing compounds, such as $\mathrm{H}_{3}$ Tri- $\mathrm{NO} x$, which allows for obtaining much higher REE enrichment (until 94\%) [106].

So, it can be seen, that work on developing an efficient and ecological method of REE recovery from fly ash should be continued. One of the solutions may be the introduction of efficient technology of REE leaching from waste after coal combustion and for separating individual REEs from the complex extracts with extreme $\mathrm{pH}$ and REE low concentrations, compared to other matrix components. For this purpose, membrane techniques or techniques based on ionic liquids can be used. Considering the above-mentioned data, it should be stated that the most effective method of REE recovery from ashes (Figure 3) would be to combine physical methods, like magnetic and size separation with acid leaching under appropriate conditions, eventually combined with roasting with $\mathrm{NaOH}$. Then removal of matrix elements from leachates using ILs, and finally REE separation using membrane methods based on HFLM and IIPs membranes (recovery above 90\%). 


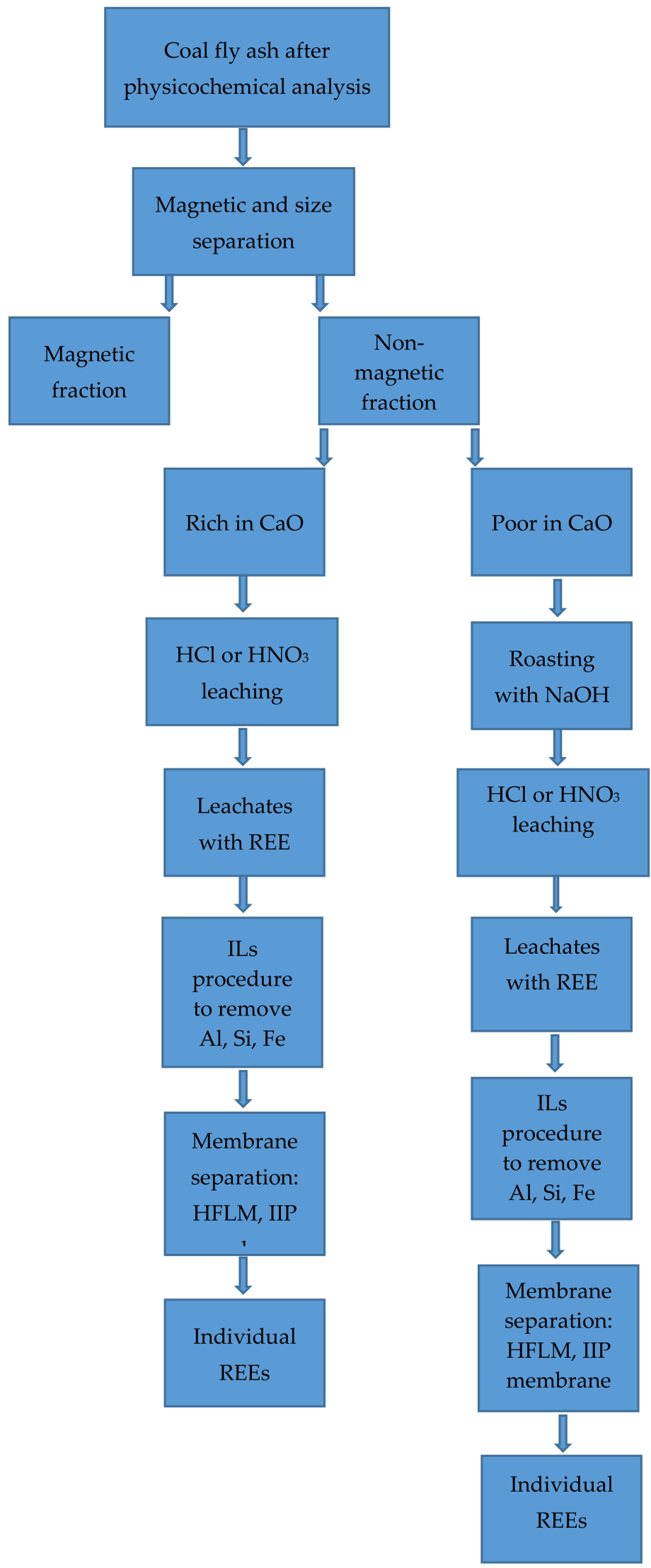

Figure 3. Scheme of the proposed procedure for the recovery of REEs from coal fly ash. 


\section{Conclusions}

The above paper covered the issues related to the characteristics, application, and selected methods of REE recovery from coal fly ashes. They are elements that, due to unique physical and chemical properties, find a wide range of applications, especially in modern technologies. In this paper, a price analysis for four selected REEs: $\mathrm{Nd}, \mathrm{Pr}, \mathrm{Tb}$, and Dy and a price forecast until 2021 were carried out. Based on this analysis, authors confirmed the profitability of investments related to REE production and the need to search for appropriate sources of these elements. It was found that coal fly ashes could be a perfect REE source, because of a lack of adequate REE deposits in EU, their huge amount (750 million tons annually from which only 30\% are utilized; from 1 ton, REE recovery worth 600 USD), high fraction of critical REE, and environmental problems with their storage. Therefore, the focus should now be on finding a cost-effective and environmentally friendly method of recovering REE from coal fly ashes.

The development of the REE recovery technology would involve solving several problems related to REE speciation, optimization of factors controlling their extractivity, and selection of REE separation method from obtained extraction solutions with a very extreme $\mathrm{pH}$ and complicated composition. The paper presents advantages and disadvantages of usually used methods of REE separation from coal fly ashes, like physical and acidbase leaching. It was also presented alternative REE recovery techniques in the form of membrane and biological methods and based on ILs or chelating agents. The directions of further modifications, which will allow the efficient REE recovery, were presented. During the research, it was found that currently none of the proposed techniques shows adequate efficiency. Therefore, the aim of this article was to propose specific solutions based on the creation of the appropriate multistage method of REE recovery. It will be a combination of magnetic and size separation, acid-base leaching (including roasting in justified cases), removal of matrix elements with ILs ( $\mathrm{Al}, \mathrm{Si}$, and $\mathrm{Fe}$ ), and finally REE membrane separation (multistage HFLM or IIPs), allowing for obtaining the appropriate process efficiency.

Author Contributions: Conceptualization, A.R. (Aleksandra Rybak) and A.R. (Aurelia Rybak); Methodology, A.R. (Aleksandra Rybak) and A.R. (Aurelia Rybak); Software, A.R. (Aleksandra Rybak) and A.R. (Aurelia Rybak); Writing-Original Draft Preparation, A.R. (Aleksandra Rybak) and A.R. (Aurelia Rybak). All authors have read and agreed to the published version of the manuscript.

Funding: This research did not receive any specific grant from funding agencies in the public, commercial, or not-for-profit sectors.

Institutional Review Board Statement: Not applicable.

Informed Consent Statement: Not applicable.

Data Availability Statement: The data presented in this study are available on request from the corresponding author. The data are not publicly available due to the extremely large size.

Acknowledgments: The authors would like to thank Alexandre Chagnes for his advice and comments.

Conflicts of Interest: The authors declare no conflict of interest.

$\begin{array}{ll}\text { Abbreviations } & \\ {\left[\mathrm{A}_{336}\right]\left[\mathrm{CA}_{12}\right]} & \text { tricaprylmethylammonium sec-octylphenoxy acetic acid } \\ {\left[\mathrm{A}_{336}\right]\left[\mathrm{CA}_{100}\right]} & \begin{array}{l}\text { tricaprylmethylammonium sec-nonylphenoxy acetic acid } \\ \text { aminopolycarboxylate chelating agents }\end{array} \\ \text { APCs } & \text { Appalachian } \\ \text { App } & \text { coal fly ash } \\ \text { CFA } & \text { (bis/2,4,4-trimethylpentyl/phosphinic acid) } \\ \text { Cyanex } 272 & \text { di-nonyl phenyl phosphoric acid } \\ \text { DNPPA } & \end{array}$




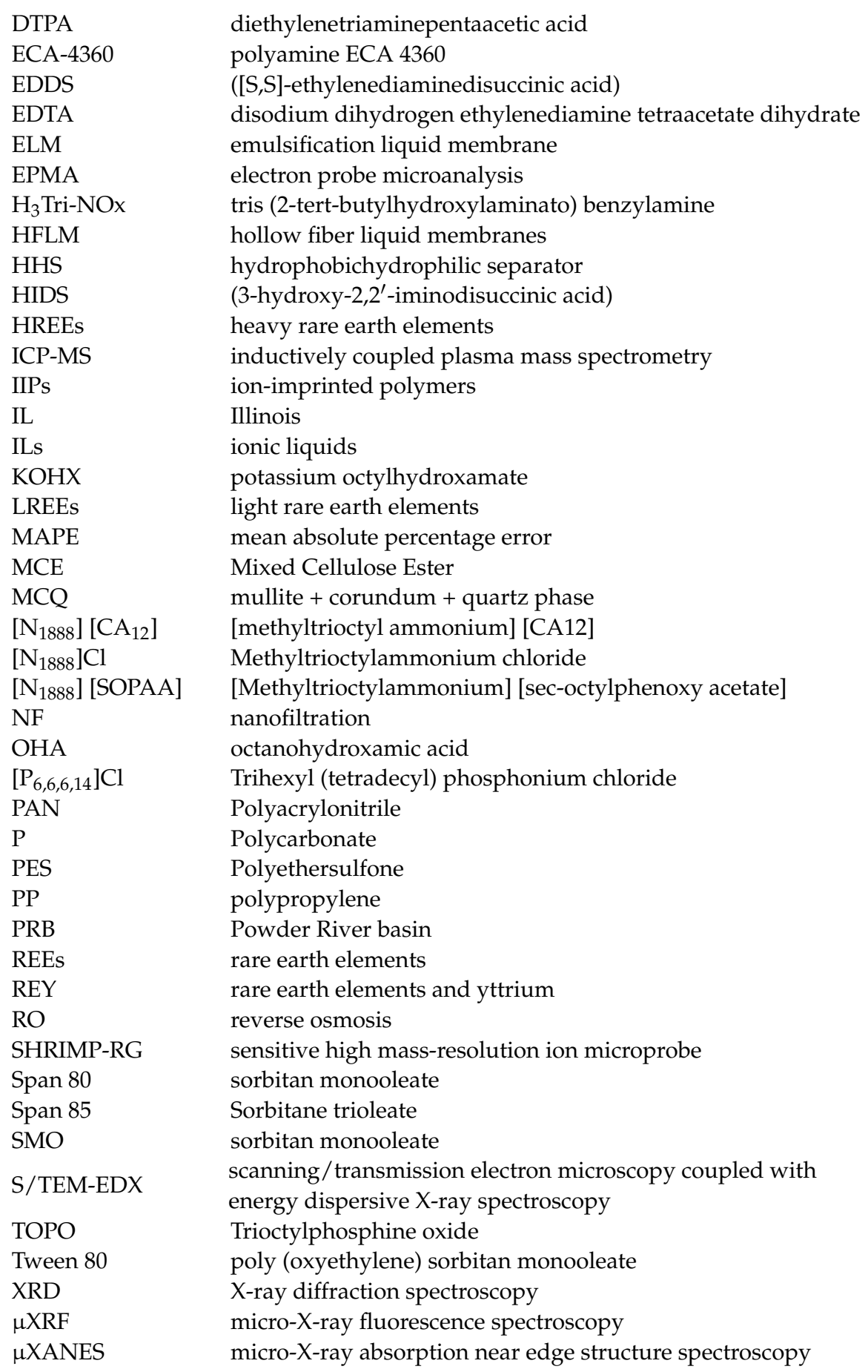

\section{References}

1. Balaram, V. Rare earth elements: A review of applications, occurrence, exploration, analysis, recycling, and environmental impact. Geosci. Front. 2019, 10, 1285-1303. [CrossRef]

2. Castor, S.B.; Hendrik, J.B. Industrial Minerals and Rocks: Commodities, Markets and Uses; Society of Mining Mineralogy: Englewood, CO, USA, 2006; Volume 7, pp. 769-792.

3. Xiong, X.; Liu, X.; Yu, I.K.M.; Wang, L.; Zhou, J.; Sun, X.; Rinklebe, J.; Shaheen, S.M.; Sik Ok, Y.; Lin, Z.; et al. Potentially toxic elements in solid waste streams: Fate and management approaches. Environ. Pollut. 2019, 253, 680-707. [CrossRef] [PubMed]

4. Zepf, V. Rare Earth Elements; Springer: Berlin/Heidelberg, Germany, 2013.

5. Liu, P.; Huang, R.; Tang, Y. Comprehensive Understandings of Rare Earth Element (REE) Speciation in Coal Fly Ashes and Implication for REE Extractability. Environ. Sci. Technol. 2019, 53, 5369-5377. [CrossRef] [PubMed]

6. Dutta, T.; Kim, K.H.; Uchimiya, M.; Kwon, E.E.; Jeon, B.H.; Deep, A.; Yun, S.T. Global demand for rare earth resources and strategies for green mining. Environ. Res. 2016, 150, 182-190. [CrossRef] [PubMed] 
7. Khan, A.M.; Kartini, N.; Bakar, A.; Farid, A.; Bakar, A.; Ashraf, M.A. Chemical speciation and bioavailability of rare earth elements (REEs) in the ecosystem: A review. Environ. Sci. Pollut. Res. 2017, 24, 22764-22789. [CrossRef] [PubMed]

8. Gupta, C.K.; Krishnamurthy, N. Extractive Metallurgy of Rare Earths; CRC Press Taylor and Francis: Boca Raton, FL, USA, 2004.

9. Weng, Z.H.; Jowitt, S.M.; Mudd, G.M.; Haque, N. Assessing rare earth element mineral deposit types and links to environmental impacts. Appl. Earth Sci. Trans. Inst. Miner. Metall. B 2013, 122, 83-96. [CrossRef]

10. Encyclopaedia Britannica. Available online: https:/ /www.britannica.com/science/rare-earth-element (accessed on 23 December 2020).

11. Taggart, R.K.; Hower, J.C.; Hsu-Kim, H. Effects of Roasting Additives and Leaching Parameters on the Extraction of Rare Earth Elements from Coal Fly Ash. Int. J. Coal Geol. 2018, 196, 106-114. [CrossRef]

12. US Geological Survey. Mineral Commodity Summaries; USGA: Reston, VA, USA, 2012.

13. Kogarko, L.N.; Kononova, V.A.; Orlova, M.P.; Woolley, A.R. Alkaline Rocks of the World, Part 2: Former Soviet Union; Chapman \& Hall: London, UK, 1995.

14. Mihalasky, M.J.; Tucker, R.D.; Renaud, K.; Verstraeten, I.M. Rare Earth Element and Rare Metal Inventory of Central Asia; USGS: Reston, VA, USA, 2018; Fact Sheet 2017-3089; p. 4.

15. Seredin, V.V.; Dai, S. Coal deposits as potential alternative sources for lanthanides and yttrium. Int. J. Coal Geol. 2012, 94, 67-93. [CrossRef]

16. Blissett, R.S.; Rowson, N.A. A review of the multi-component utilization of coal fly ash. Fuel 2012, 97, 1-23. [CrossRef]

17. Baba, A.; Usmen, M.A. Effects of Fly Ash from Coal-Burning Electrical Utilities on Ecosystem And Utilization of Fly Ash, Groundwater Ecosys; Springer: Berlin/Heidelberg, Germany, 2006; pp. 15-31.

18. Całus Moszko, J.; Białecka, B. Analiza możliwości pozyskania pierwiastków ziem rzadkich z węgli kamiennych i popiołów lotnych z elektrowni. Gospod. Surowcami Miner-Miner. Resour. Manag. 2013, 29, 67-80.

19. King, J.F.; Taggart, R.K.; Smith, R.C.; Hower, J.C.; Hsu-Kim, H. Aqueous acid and alkaline extraction of rare earth elements from coal combustion ash. Int. J. Coal Geol. 2018, 195, 75-83. [CrossRef]

20. Franus, W.; Wiatros-Motyka, M.M.; Wdowin, M. Coal fly ash as a resource for rare earth elements. Environ. Sci. Pollut. Res. 2015, 22, 9464-9474. [CrossRef] [PubMed]

21. Wdowin, M.; Franus, W. Analiza popiołów lotnych pod katem uzyskania z nich pierwiastków ziem rzadkich. Polityka Energetyczna 2014, 17, 369-380.

22. Querol, X.; Moreno, N.; Umaña, J.C.; Alastuey, A.; Hernández, E.; López-Soler, A. Synthesis of zeolites from coal fly ash: An overview. Int. J. Coal. Geol. 2002, 50, 413-423. [CrossRef]

23. Liyanage, M.; Jayaranjan, D.; van Hullebusch, E.D.; Annachhatre, A.P. Reuse options for coal fired power plant bottom ash and fly ash. Rev. Environ. Sci. Biotechnol. 2014, 13, 467-486.

24. Korcak, R. Agricultural uses of coal combustion byproducts. In: Agricultural uses of municipal, animal and industrial byproducts. USDA-ARS Conserv. Res. Rep. 1998, 44, 103-119.

25. Kucowski, J.; Laudyn, D.; Przekwas, M. Energetyka a Ochrona Środowiska; WNT: Warszawa, Poland, 1997 ; p. 395.

26. KITCO. Available online: https://www.kitco.com/strategic-metals/ (accessed on 10 September 2019).

27. Sen, P.; Roy, M.; Pal, P. Application of ARIMA for forecasting energy consumption and GHG emission: A case study of an Indian pig iron manufacturing organization. Energy 2016, 116, 1031-1038. [CrossRef]

28. Yaltaa, A.T.; Jenal, O. On the importance of verifying forecasting results. Int. J. Forecast. 2009, 25, 62-73. [CrossRef]

29. Gruszczyński, M.; Podgórska, M. Ekonometria; Oficyna Wydawnicza SGH: Warszawa, Poland, 2007.

30. Myttenaere, A.; Golden, B.; Grand, B.; Rossi, F. Mean Absolute Percentage Error for regression models. Neurocomputing 2016, 192, 38-48. [CrossRef]

31. Jarosiński, A. Wybrane Zagadnienia Z Technologii Pozyskiwania Metali Ziem Rzadkich; IGSMiE PAN: Krakow, Poland, 2016.

32. TAURON. Available online: https://www.tauron.pl/tauron (accessed on 10 September 2019).

33. Hood, M.M.; Taggart, R.K.; Smith, R.C.; Hsu-kim, H.; Henke, K.R.; Graham, U.; Groppo, J.G.; Unrine, J.M.; Hower, J.C. Rare earth element distribution in fly Ash derived from the fire clay coal. Coal Combust. Gasif. Prod. 2017, 9, 22-33. [CrossRef]

34. Vassilev, S.V.; Menendez, R.; Alvarez, D.; Diaz-Somoano, M.; Martinez-Tarazona, M.R. Phase-mineral and chemical composition of coal fly ashes as a basis for their multicomponent utilization. 1. Characterization of feed coals and fly ashes. Fuel 2003, 82, 1793-1811. [CrossRef]

35. Yan, X.; Dai, S.; Graham, I.T.; He, X.; Shan, K.; Liu, X. Determination of Eu concentrations in coal, fly ash and sedimentary rocks using a cation exchange resin and inductively coupled plasma mass spectrometry (ICP-MS). Int. J. Coal Geol. 2018, 191, 152-156. [CrossRef]

36. Li, X.; Dai, S.; Zhang, W.; Li, T.; Zheng, X.; Chen, W. Determination of As and Se in coal and coal combustion products using closed vessel microwave digestion and collision/reaction cell technology (CCT) of inductively coupled plasma mass spectrometry (ICP-MS). Int. J. Coal Geol. 2014, 124, 1-4. [CrossRef]

37. Baker, J.; Waight, T.; Ulfbeck, D. Rapid and highly reproducible analysis of the rare earth elements by multiple collector ICP-MS. Geochim. Cosmochim. Acta 2002, 66, 3635-3646. [CrossRef]

38. Honaker, R.Q.; Groppo, J.; Yoon, R.-H.; Luttrell, G.H.; Noble, A.; Herbst, J. Process evaluation and flowsheet development for the recovery of rare earth elements from coal and associated byproducts. Miner. Metall. Proc. 2017, 34, 107-115. [CrossRef]

39. Zhang, W.; Yang, X.; Honaker, R.Q. Association characteristic study and preliminary recovery investigation of rare earth elements from Fire Clay seam coal middlings. Fuel 2018, 215, 551-560. [CrossRef] 
40. Kolker, A.; Scott, C.; Hower, J.C.; Vazquez, J.A.; Lopano, C.L.; Dai, S. Distribution of rare earth elements in coal combustion fly ash, determined by SHRIMP-RG ion microprobe. Int. J. Coal Geol. 2017, 184, 1-10. [CrossRef]

41. Lin, R.; Howard, B.H.; Roth, E.A.; Bank, T.L.; Granite, E.J.; Soong, Y. Enrichment of rare earth elements from coal and coal by-products by physical separations. Fuel 2017, 200, 506-520. [CrossRef]

42. Hower, J.C.; Dai, S.; Seredin, V.V.; Zhao, L.; Kostova, I.J.; Silva, L.F.O. A note on the occurrence of yttrium and rare earth elements in coal combustion products. Coal Combust. Gasificat. Prod. 2013, 5, 39-47.

43. Blissett, R.S.; Smalley, N.; Rowson, N.A. An investigation into six coal fly ashes from the United Kingdom and Poland to evaluate rare earth element content. Fuel 2014, 119, 236-239. [CrossRef]

44. Dai, S.; Yan, X.; Ward, C.R.; Hower, J.C.; Zhao, L.; Wang, X. Valuable elements in Chinese coals: A review. Int. Geol. Rev. 2016, 60, 1-31. [CrossRef]

45. Dai, S.; Zhao, L.; Peng, S.; Chou, C.-L.; Wang, X.; Zhang, Y. Abundances and distribution of minerals and elements in high-alumina coal fly ash from the Jungar Power Plant, Inner Mongolia, China. Int. J. Coal Geol. 2010, 81, 320-332. [CrossRef]

46. Dai, S.; Zhao, L.; Hower, J.C.; Johnston, M.N.; Song, W.; Wang, P. Petrology, mineralogy, and chemistry of size-fractioned fly ash from the Jungar power plant, Inner Mongolia, China, with emphasis on the distribution of rare earth elements. Energy Fuel 2014, 28, 1502-1514. [CrossRef]

47. Davison, R.L.; Natusch, D.F.S.; Wallace, J.R.; Evans, C.A. Trace elements in fly ash dependence of concentration on particle size. Environ. Sci. Technol. 1974, 8, 1107-1113. [CrossRef]

48. Wang, Z.; Dai, S.; Zou, J.; French, D.; Graham, I.T. Rare earth elements and yttrium in coal ash from the Luzhou power plant in Sichuan, Southwest China: Concentration, characterization and optimized extraction. Int. J. Coal Geol. 2019, 203, 1-14. [CrossRef]

49. Bai, G.; Qiao, Y.; Shen, B.; Chen, S. Thermal decomposition of coal fly ash by concentrated sulfuric acid and alumina extraction process based on it. Fuel Process. Technol. 2011, 92, 1213-1219. [CrossRef]

50. Kelmers, A.D.; Canon, R.M.; Egan, B.Z.; Felker, L.K.; Gilliam, T.M.; Jones, G.; Owen, G.D.; Seeley, F.G.; Watson, J.S. Chemistry of the direct acid leach, calsinter, and pressure digestion-acid leach methods for the recovery of alumina from fly ash. Resour. Conserv. 1982, 9, 271-279. [CrossRef]

51. Nayak, N.; Panda, C.R. Aluminium extraction and leaching characteristics of Talcher thermal Power Station fly ash with sulphuric acid. Fuel 2010, 89, 53-58. [CrossRef]

52. Seidel, A.; Zimmels, Y. Mechanism and kinetics of aluminum and iron leaching from coal fly ash by sulfuric acid. Chem. Eng. Sci. 1998, 53, 3835-3852. [CrossRef]

53. Kashiwakura, S.; Kumagai, Y.; Kubo, H.; Wagatsuma, K. Dissolution of Rare Earth Elements from Coal Fly Ash Particles in a Dilute $\mathrm{H}_{2} \mathrm{SO}_{4}$ Solvent. Open J. Phys. Chem. 2013, 3, 69-75. [CrossRef]

54. Peiravi, M.; Ackah, A.; Guru, R.; Liu, J.; Mohanty, M. Chemical extraction of rare earth elements from coal ash. Miner. Metall. Process. 2017, 34, 170-177. [CrossRef]

55. Cao, S.; Zhou, C.; Pan, J.; Liu, C.; Tang, M.; Ji, W.; Hu, T.; Zhang, N. Study on Influence Factors of Leaching of Rare Earth Elements from Coal Fly Ash. Energy Fuels 2018, 327, 8000-8005. [CrossRef]

56. Bradło, D.; Żukowski, W.; Czupryński, P.; Witkowski, K. Potential of Metal Recovery from Coal Combustion Products. Part II. Leaching of Selected Elements. J. Pol. Miner. Eng. Soc. 2015, 16, 163-170.

57. Lin, R.; Stuckman, M.; Howard, B.H.; Bank, T.L.; Roth, E.A.; Macala, M.K.; Lopano, C.; Soong, Y.; Granite, E.J. Application of sequential extraction and hydrothermal treatment for characterization and enrichment of rare earth elements from coal fly ash. Fuel 2018, 232, 124-133. [CrossRef]

58. Sahoo, P.K.; Kim, K.; Powell, M.A.; Equeenuddin, S.M. Recovery of metals and other beneficial products from coal fly ash: A sustainable approach for fly ash management. Int. J. Coal Sci. Technol. 2016, 3, 267-283. [CrossRef]

59. Yao, Z.T.; Xia, M.S.; Sarker, P.K.; Chen, T. A review of the alumina recovery from coal fly ash, with a focus in China. Fuel 2014, 120, 74-85. [CrossRef]

60. Meier, A.L.; Lichte, F.E.; Briggs, P.H.; Bullock, J.H., Jr. Coal Ash by Inductively Coupled Plasma-Atomic Emission Spectrometry and Inductively Coupled Plasma-Mass Spectrometry. In Analytical Methods Manual for the Mineral Resources Surveys Program; Arbogast, B.F., Ed.; U.S. Geological Survey: Denver, CO, USA, 1996.

61. Meier, A.L.; Slowik, T. Rare earth elements by inductively coupled plasma-mass spectrometry (Version 5.0 Ed.). In Analytical Methods for Chemical Analysis of Geologic and Other Materials; Taggart, J.E., Jr., Ed.; U.S. Geological Survey: Reston, VA, USA, 2002.

62. Nugroho, N.D.; Rosita, W.; Perdana, I.; Bendiyasa, I.M.; Mufakhir, F.R.; Astuti, W. Iron bearing oxide minerals separation from rare earth elements (REE) rich coal fly ash. Mater. Sci. Eng. 2019, 478, 012026. [CrossRef]

63. Frugier, P.; Gin, S.; Minet, Y.; Chave, T.; Bonin, B.; Godon, N.; Lartigue, J.-E.; Jollivet, P.; Ayral, A.; De Windt, L.; et al. SON 68 nuclear glass dissolution kinetics: Current state of knowledge and basis of the new GRAAL model. J. Nucl. Mater. 2008, 380, 8-21. [CrossRef]

64. Gin, S.; Mestre, J.P. SON 68 nuclear glass alteration kinetics between pH 7 and pH 11.5. J. Nucl. Mater. 2001, 295, 83-96. [CrossRef]

65. Maraghechi, H.; Rajabipour, F.; Pantano, C.G.; Burgos, W.D. Effect of calcium on dissolution and precipitation reactions of amorphous silica at high alkalinity. Cem. Concr. Res. 2016, 87, 1-13. [CrossRef]

66. Mercado-Depierre, S.; Angeli, F.; Frizon, F.; Gin, S. Antagonist effects of calcium on borosilicate glass alteration. J. Nucl. Mater. 2013, 441, 402-410. [CrossRef] 
67. Gorrepati, E.A.; Wongthahan, P.; Raha, S.; Fogler, H.S. Silica precipitation in acidic solutions: Mechanism, pH effect, and salt effect. Langmuir 2010, 26, 10467-10474. [CrossRef] [PubMed]

68. Nascimento, M.; Soares, P.S.M.; Souza, V.P.D. Adsorption of heavy metal cations using coal fly ash modified by hydrothermal method. Fuel 2009, 88, 1714-1719. [CrossRef]

69. Mutlu, B.K.; Cantoni, B.; Turolla, A.; Antonelli, M.; Hsu-Kim, H.; Wiesner, M.R. Application of nanofiltration for Rare Earth Elements recovery from coal fly ash leachate: Performance and cost evaluation. Chem. Eng. J. 2018, 349, 309-317. [CrossRef]

70. Gasser, M.S.; Aly, M.I. Separation and recovery of rare earth elements from spent nickel-metal-hydride batteries using synthetic adsorbent. Int. J. Miner. Process. 2013, 121, 31-38. [CrossRef]

71. Konishi, Y.; Shimaoka, J.; Asai, S. Sorption of rare-earth ions on biopolymer gel beads of alginic acid. React. Funct. Polym. 1998, 36, 197-206. [CrossRef]

72. Murty, D.S.R.; Chakrapani, G. Preconcentration of rare earth elements on activated carbon and its application to groundwater and sea-water analysis. J. Anal. At. Spectrom. 1996, 11, 815. [CrossRef]

73. Abreu, R.D.; Morais, C.A. Purification of rare earth elements from monazite sulphuric acid leach liquor and the production of high-purity ceric oxide. Miner. Eng. 2010, 23, 536-540. [CrossRef]

74. Innocenzi, V.; De Michelis, I.; Ferella, F.; Vegliò, F. Recovery of yttrium from cathode ray tubes and lamps' fluorescent powders: Experimental results and economic simulation. Waste Manag. 2013, 33, 2390-2396. [CrossRef]

75. Shimizu, H.; Ikeda, K.; Kamiyama, Y. Refining of a Rare Earth Including a Process for Separation by a Reverse Osmosis Membrane. U.S. Patent No. 5,104,544, 14 April 1992.

76. Wen, B.; Shan, X.; Xu, S. Preconcentration of ultratrace rare earth elements in seawater with 8-hydroxyquinoline immobilized polyacrylonitrile hollow fiber membrane for determination by inductively coupled plasma mass spectrometry. Analyst 1999, 124, 621-626. [CrossRef]

77. Murthy, Z.V.P.; Gaikwad, M.S. Separation of praseodymium (III) from aqueous solutions by nanofiltration. Can. Metall. Q. 2013, 52, 18-22. [CrossRef]

78. Qin, Q.W.; Zhao, H.Q.; Lai, Y.Q.; Li, J.; Liu, Y.X.; Deng, Z.G. Extraction of rare earth metals by liquid surfactant membranes containing Cyanex272 as a carrier. Miner. Metallurg. Eng. 2002, 22, 74-78.

79. Davoodi-Nasab, P.; Rahbar-Kelishami, A.; Safdari, J.; Abolghasemi, H. Application of emulsion nanofluids membrane for the extraction of gadolinium using response surface methodology. J. Mol. Liq. 2017, 244, 368-373. [CrossRef]

80. Wannachod, P.; Chaturabul, S.; Pancharoen, U.; Lothongkum, A.W.; Patthaveekongka, W. The effective recovery of praseodymium from mixed rare earths via a hollow fiber supported liquid membrane and its mass transfer related. J. Alloy. Compd. 2011, 509, 354-361. [CrossRef]

81. Ambare, D.N.; Ansari, S.A.; Anitha, M.; Kandwal, P.; Singh, D.K.; Singh, H.; Mohapatra, P.K. Non-dispersive solvent extraction of neodymium using a hollow fiber contactor: Mass transfer and modeling studies. J. Membr. Sci. 2013, 446, 106-112. [CrossRef]

82. Zheng, X.; Zhang, F.; Liu, E.; Xu, X.; Yan, Y. Efficient recovery of neodymium in acidic system by free-standing dual-template docking oriented ionic imprinted mesoporous films. ACS Appl. Mater. Inter. 2017, 9, 730-739. [CrossRef]

83. Liu, E.; Xu, X.; Zheng, X.; Zhang, F.; Liu, E.; Li, C. An ion imprinted macroporous chitosan membrane for efficiently selective adsorption of dysprosium. Sep. Purif. Technol. 2017, 189, 288-295. [CrossRef]

84. Park, S.; Liang, Y. Bioleaching of trace elements and rare earth elements from coal fly ash. Int. J. Coal Sci. Technol. 2019, 6, 74-83. [CrossRef]

85. Sutar, A.S.; Awasare, S.D. Bioleaching of ore using chemolithotrophic microorganisms (Acidithiobacillus ferrooxidans). Int. J. Res. Environ. Sci. Technol. 2015, 5, 14-21.

86. Karwowska, E.; Andrzejewska-Morzuch, D.; Łebkowska, M.; Tabernacka, A.; Wojtkowska, M.; Telepko, A.; Konarzewska, A. Bioleaching of metals from printed circuit boards supported with surfactant-producing bacteria. J. Hazard. Mater. 2014, 264, 203-210. [CrossRef]

87. Karwowska, E.; Wojtkowska, M.; Andrzejewska, D. The influence of metal speciation in combustion waste on the efficiency of $\mathrm{Cu}, \mathrm{Pb}, \mathrm{Zn}, \mathrm{Cd}, \mathrm{Ni}$ and $\mathrm{Cr}$ bioleaching in a mixed culture of sulfuroxidizing and biosurfactant-producing bacteria. J. Hazard. Mater. 2015, 299, 35-41. [CrossRef]

88. Mishra, D.; Rhee, Y.H. Microbial leaching of metals from solid industrial wastes. J. Microbiol. 2014, 52, 1-7. [CrossRef]

89. Schippers, A.; Hedrich, S.; Vasters, J.; Drobe, M.; Sand, W.; Willscher, S. Biomining: Metal Recovery from Ores with Microorganisms. Geobiotechnology; Springer: Berlin, Germany, 2013; pp. 1-47.

90. Goyne, K.W.; Brantley, S.L.; Chorover, J. Rare earth element release from phosphate minerals in the presence of organic acids. Chem. Geol. 2010, 278, 1-14. [CrossRef]

91. Shin, D.; Kim, J.; Kim, B.-S.; Jeong, J.; Lee, J.-C. Use of phosphate solubilizing Bacteria to leach rare earth elements from monazite-bearing ore. Minerals 2015, 5, 189-202. [CrossRef]

92. Ibrahim, H.; El-Sheikh, E. Bioleaching treatment of Abu Zeneima uraniferous gibbsite ore material for recovering $\mathrm{U}, \mathrm{REEs,} \mathrm{Al}$ and Zn. Res. J. Chem. Sci. 2011, 1, 55-66.

93. Hassanien, W.A.G.; Desouky, O.A.N.; Hussien, S.S.E. Bioleaching of some rare earth elements from Egyptian monazite using Aspergillus ficuum and Pseudomonas aeruginosa. Walailak J. Sci. Technol. 2013, 11, 809-823.

94. Muravyov, M.I.; Bulaev, A.G.; Melamud, V.S.; Kondrat'eva, T.F. Leaching of Rare Earth Elements from Coal Ashes Using Acidophilic Chemolithotrophic Microbial Communities. Microbiology 2015, 84, 194-201. [CrossRef] 
95. Desouky, O.A.; El-Mougith, A.A.; Hassanien, W.A.; Awadalla, G.S.; Hussien, S.S. Extraction of some strategic elements from thorium-uranium concentrate using bioproducts of Aspergillus ficuum and Pseudomonas aeruginosa. Arab. J. Chem. 2011, 9, 795-805. [CrossRef]

96. Wilkes, J.S. A short history of ionic liquids-from molten salts to neoteric solvents. Green Chem. 2002, 4, 73-80. [CrossRef]

97. Mallah, M.H.; Shemirani, F.; Maragheh, M.G. Ionic liquids for simultaneous preconcentration of some lanthanoids using dispersive liquid-liquid microextraction technique in uranium dioxide powder. Environ. Sci. Technol. 2009, 43, 1947-1951. [CrossRef]

98. Sun, X.Q.; Luo, H.M.; Dai, S. Ionic liquids-based extraction: A promising strategy for the advanced nuclear fuel cycle. Chem. Rev. 2012, 112, 2100-2128. [CrossRef] [PubMed]

99. Sun, X.Q.; Waters, K.E. Synergistic effect between bifunctional ionic liquids and a molecular extractant for lanthanide separation. ACS Sustain. Chem. Eng. 2014, 2, 2758-2764. [CrossRef]

100. Mishra, R.K.; Rout, P.C.; Sarangi, K.; Nathsarma, K.C. Solvent extraction of Fe (III) from the chloride leach liquor of low-grade iron ore tailings using Aliquat 336. Hydrometallurgy 2011, 108, 93-99. [CrossRef]

101. Wang, L.; Sun, H.; Sun, Z. New technology and application of brick making with coal fly ash. Mater. Cycles Waste Manag. 2016, 18, 763-770. [CrossRef]

102. Wang, W.; Yang, H.; Cui, H.; Zhang, D.; Liu, Y.; Chen, J. Application of Bifunctional Ionic Liquid Extractants [A336][CA-12] and [A336][CA-100] to the Lanthanum Extraction and Separation from Rare Earths in the Chloride Medium. Ind. Eng. Chem. Res. 2011, 50, 7534-7541. [CrossRef]

103. Dong, Y.M.; Sun, X.Q.; Wang, Y.L.; Huang, C.; Zhao, Z.Y. The sustainable and efficient ionic liquid type saponification strategy for rare earth separation processing. ACS Sustain. Chem. Eng. 2016, 4, 1573-1580. [CrossRef]

104. Huang, C.; Wang, Y.; Huang, B.; Dong, Y.; Sun, X. The recovery of rare earth elements from coal combustion products by ionic liquids. Miner. Eng. 2019, 130, 142-147. [CrossRef]

105. Hasegawa, H.; Rahman, I.M.M.; Egawa, Y.; Sawai, H.; Begum, Z.A.; Maki, T.; Mizutani, S. Recovery of the Rare Metals from Various Waste Ashes with the Aid of Temperature and Ultrasound Irradiation Using Chelants. Water Air Soil Pollut. 2014, 225, 2112. [CrossRef]

106. Fang, H.; Cole, B.E.; Qiao, Y.; Bogart, J.A.; Cheisson, T.; Manor, B.C.; Carroll, P.J.; Schelter, E.J. Electro-kinetic separation of rare earth elements using a redox-active ligand. Angew. Chem. Int. Edit. 2017, 56, 13450-13454. [CrossRef] 